
Not for reproduction, distribution or commercial use.

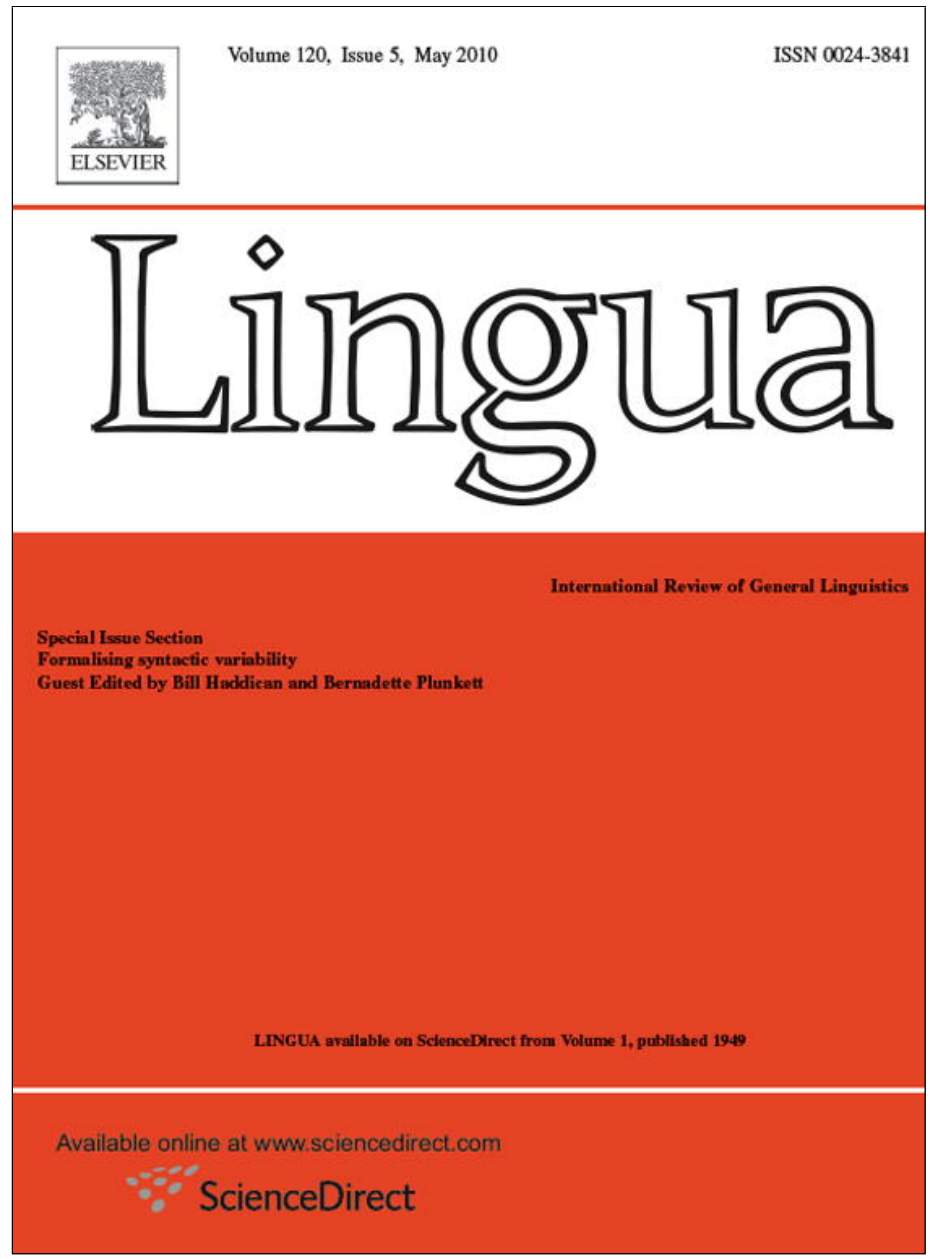

This article appeared in a journal published by Elsevier. The attached copy is furnished to the author for internal non-commercial research and education use, including for instruction at the authors institution and sharing with colleagues.

Other uses, including reproduction and distribution, or selling or licensing copies, or posting to personal, institutional or third party websites are prohibited.

In most cases authors are permitted to post their version of the article (e.g. in Word or Tex form) to their personal website or institutional repository. Authors requiring further information regarding Elsevier's archiving and manuscript policies are encouraged to visit:

http://www.elsevier.com/copyright 


\title{
Bulgarian relative and factive clauses with an invariant complementizer
}

\author{
Iliyana Krapova* \\ Department of American, Iberian and Slavic Studies, University of Venice, Ca' Bernardo, Dorsoduro 3199, Venice 30123, Italy \\ Received 30 January 2009; received in revised form 4 August 2009; accepted 5 August 2009 \\ Available online 8 November 2009
}

\begin{abstract}
The paper offers an analysis of Bulgarian relative clauses introduced by the invariant complementizer deto 'that', whose distribution also extends to factive contexts. Using reconstruction as primary evidence for movement, I review the basic facts for its presence (amount readings, idiom interpretation, binding and scope) and absence (Principle C) and argue that both a raising and a matching analysis must be available for the derivation of deto-relatives. I also discuss the distribution and structural properties of resumptive clitics which are shown to block reconstruction in all types of contexts and hence to be compatible with a matching derivation only. Given the structural ambiguity in the derivation of Bulgarian complementizer relatives and in search of a unified treatment of their potentially ambivalent behavior, the paper applies Cinque's $(2003,2008)$ analysis of relative clauses, which postulates two identical copies of the relativized Head (internal and external) and exploits different movement options to account for the raising and the matching derivations. It is then argued that such a proposal, which also exploits distinct CP positions, can successfully accommodate all of the observed reconstruction effects (or lack thereof), including the option of resumption. The paper also offers a discussion of factive clauses introduced by the same complementizer and proposes that they are best treated as hidden relatives embedded under a more complex structure involving a PP projection and a silent D head.
\end{abstract}

(C) 2009 Elsevier B.V. All rights reserved.

Keywords: Relative clauses; Complementizer relatives; Resumption; Clitics; Reconstruction; Islands; Factive clauses

\section{Introduction}

Bulgarian possesses an invariant subordinator, deto, which can be used in headed relative clauses and also as a subordinating conjunction introducing complement clauses of some emotive factive predicates. The two uses are illustrated in (1a) and (1b).

a. Tova e čovekăt, deto (go)

snimax včera.

this is man-the that him-ClAcc photographed-1sg yesterday

'This is the man that I photographed yesterday'

b. Săžaljavam, deto ne možax da dojda. regret-1sg that not could-1sg Mod come-1sg 'I regret that I couldn't come'

\footnotetext{
* Tel.: +39041 2349451; fax: +390412349469.

E-mail address: krapova@unive.it.
} 
Building on work by Rudin (1986), in this paper I will further examine the properties and distribution of deto, in an attempt to propose a unified account for (1a) and (1b). The underlying idea is that deto is a complementizer but of a specific type, namely a relative complementizer, and as such it is bound to occur in relative clauses (RCs) only. Support for this proposal will come from the analysis of clauses like (1b) which, differently from other factive clauses, introduced by the default complementizer $\check{c} e$ 'that', are shown to instantiate a hidden relative structure, whose head is the null variant of the demonstrative tova 'this'. Thus, the structural difference between (1a) and (1b) can be attributed to properties of the relativized head (overt or covert), rather than to the type of clause involved in each case.

In section 2, I will present some basic facts concerning the distribution of deto-relative clauses and the possibilities they present with respect to resumption. In section 3, I will discuss the available theoretical options for deriving relative clauses (RCs), comparing the well-known raising and matching analyses, and will argue that both are needed for the structural description of deto-relatives. I will then, in section 4, show that Cinque's (2003, 2008, in preparation) analysis, which postulates a prenominal Merge of the RC for the derivation of all types of relative clauses, can account successfully for all of the observed properties of deto-relatives, including the specifics of resumption. In section 5, I will discuss the basic facts of the apparent complementation phenomenon of (1b) and will concentrate on the reasons for assimilating it to a relative clause structure.

\section{General overview of deto-relatives}

\subsection{Brief historical remarks}

Traditional Bulgarian grammars have paid attention mainly to the functions of deto as a relative marker (there is only a brief mention of its usage with factive verbs) and describe it as a relativum generale, capable of relativizing all sorts of lexical heads (AG, 1983:309, Nitsolova, 1986:137). Historically, deto derives from the adverbial relative pronoun kădeto 'where', the locative meaning of which, starting from Early Modern Bulgarian, gradually weakeneda process which was accompanied by a phonological reduction: kădeto $>$ gdeto/deto. ${ }^{1}$ In the 17 th and 18th century deto already appears, especially in Damaskin literature ${ }^{2}$, as a multi-purpose relativizer, synonymous to several other relativizers, such as "where", "for this reason, that", "in which", "which", "that". Cf. the examples in (2). This structural reanalysis of the wh-adverbial, based on extension of its functional meaning, gradually culminated in the contemporary use of deto as an invariable relative marker, typical of colloquial speech ${ }^{3}$ (including that of educated speakers) and particularly widespread in Bulgarian dialects, where it shows up under different phonological forms: detu/denu/det/deto/deso/deno in the Eastern dialects and dek/deka $(d e<k a \breve{d e}+k a)$ in the Western ones. Cf. Karabelova (1998) from where the examples in (3) have been taken:
a. Blažena si
ty ot sičkyte ženy,
deto si takova dete rodila...
deto $=$ because
blessed are-2sg you from all-the women that are-2sg such child born-prt-f
'You are blessed among all the women, because you gave birth to such a child...'
b. ...da ti kažem radost goljama, deto štešb da bădešb na sičkyte crykvi božii oučitelı.
deto $=$ that
to you-ClDat tell-1pl joy great that will-2sg to be-2sg to all-the churches God's teacher
'to tell you a great joy that you will be the teacher of all God's churches'
c. I dade mu deto držaše v răcete svoi ključovete.
and gave-3sg him-ClDat that held-3sg in hands-the his-refl keys-the
'And he gave him the keys that he was holding in his hands'

Trojanski damaskin, 17th c., p. 43, Dacheva, Tisheva (2005)

\footnotetext{
${ }^{1}$ The relative adverbial itself derives from the interrogative adverbial kăde 'where', to which the anaphoric definiteness marker -to has been added.

${ }^{2}$ Miscellanea collections of religious precepts and parables written in colloquial style.

${ }^{3}$ The reason deto did not enter the standard language are extralinguistic and have to do with the strong normative tradition which prevailed in the modern period of the language, coupled with Church Slavonic influences introduced artificially through literary communication. These tendencies brought about a restoration of deto's original locative meaning in the written form of the language, while its other usages got restricted to the colloquial register (Dacheva and Tisheva, 2005).
} 

d. ... i vъ toa grad Antioxia, beše i monastirı, deto se blažennij Ioannь postriže... deto $=$ where and in this town Antioch was also monastery that refl blessed John became-monk
'And in this town of Antioch there was also a monastery where the blessed John became a monk.' Svištovski damaskin 1753, p. 23, Dacheva (2008)
(3) a. ... či mi ni stigat za turbine, denu xi tkaje. (The Rhodopes, Eastern dialects) because me-CIDat not suffice-3pl for sacks-the that them-ClAcc weave-1sg 'Because they are not enough for the sacks that I am weaving'
b. Koj beši čuvekăd, detu mu dadi pariti? who was-3sg man-the that him-ClDat gave-2sg money-the 'Who was the man that you gave the money to?'
c. Devojčeto, deka beše daskalica, ga tražiše edni òr. (Godeč, Western dialects) girl-the that was-3sg teacher her-ClAcc looked-for-3pl some people 'Some people were looking for the girl that used to be a teacher' (Panagjurište, Balkan dialects)

\subsection{Complementizer properties of deto}

Bulgarian is not unique among the Slavic languages in using an uninflected complementizer as a relativum generale, alongside a relative pronoun. The same strategy is found in many other Slavic languages: Polish co (Broihier, 1995; Pesetsky, 1998; Szczegielniak, 2005); Czech co (Toman, 1998); Russian čto (Lavine, 2003; Szczegielniak, 2005); Slovenian ki, Serbo-Croatian što (Browne, 1986; van der Auwera and Kučanda, 1985); Ukrainian $\check{s} c o$ (Lavine, 2003) and Macedonian što (Gareiss, 1999; Topolinjska, 1997). Outside Slavic, well-known cases of invariable relativizers include Swiss German wo (Riemsdijk, 1989; Salzmann, 2006); Greek pu (Stavrou, 1984; Alexiadou, 1998; Alexiadou and Anagnostopoulou, 1999); Albanian që (Kallulli, 2008), English that (at least in some varieties of English). Among the Slavic languages Bulgarian however seems to be unique in two respects: (1) it is the only language in which the invariable relative marker is associated diachronically with the $w h$-adverbial where, and (2) it is the only language which (apparently) has extended the use of the relative marker into the domain of sentential complementation, as in (1b) above. Outside Slavic Bulgarian seems to pattern in both of these respects with Greek where too an adverbial complementizer ( $p u$ 'where/that') is used in factive/emotive complements, in addition to relative clauses.

One property that deto shares with invariable relative markers in other languages is that it is not marked for case and hence does not bear the case assigned to the relative clause internal gap. Neither is it marked for number and gender. In these two respects it differs crucially from relative pronouns which distinguish three genders in the singular and a plural form, and two case forms-nominative and accusative for masculine animates. Cf. (4) and in particular, compare (4b) with (1a) above:
a. Tova e čovekăt, kojto
me
snima
včera
this is man-the who-m-Nom me-ClAcc photographed-3sg yesterday
'This is the man who photographed me yesterday'
b. Tova e čovekăt, kogoto snimax včera
this is man-the whom-m-Acc photographed-1sg yesterday
'This is the man whom I photographed yesterday'
c. Tova e ženata, kojato snimax včera.
this is woman-the who-fem photographed-1sg yesterday
'This is the woman whom I photographed yesterday'

The absence of Case features in deto is the most important argument advanced by Rudin (1986:130) in favour of its complementizer status. Another potential argument that Rudin offers is that if deto were a relative pronoun, it would be able to pied-pipe a preposition, given the impossibility of preposition stranding in Bulgarian. However, this is not the case, as (5a) shows. The only way the ungrammaticality of (5a) can be repaired is to use a resumptive pronoun as the object of the preposition, (5b), a strategy unavailable in $w h$-relatives, (5d), since the preposition here is needed to assign Case to the relative pronoun, $(5 \mathrm{c})$ : 
(5) a. *ženata, $s$ deto govorix woman-the with that talked-1sg

(Rudin 1986:131, ex. (18))

b. ženata, deto govorix s neja woman-the that talked-1sg with her-Acc

'the woman that I talked with'

c. ženata, skojato govorix woman-the with who-fem talked-1sg 'the woman with whom I talked'

d.*ženata, kojato govorix s neja woman-the who-fem talked with her-Acc

The contrasts in (5) therefore can be made sense of if deto is generated directly in $\mathrm{C}$, while the $w h$-pronoun is moved to Spec,CP.

A third argument for complementizer status comes from co-occurrence restrictions. While deto is incompatible with other complementizers (Bulgarian does not possess double complementizers), it is also incompatible with wh-words. This latter restriction is more significant since Bulgarian is a multiple $w h$-fronting language in both $w h$-question and free $w h$-relatives, so the ungrammaticality of $(6 \mathrm{~b}, \mathrm{~d})$ would be unexpected if deto were a wh-adverbial or a $w h$-pronoun in general $^{4}$ :

(6) a. Koj kakvoto iska, da go vzeme.

(Rudin 1986:132, ex. (20b)) who what want-3sg Mod it-ClAcc take-3sg 'Whoever wants whatever, let him take it'

$\mathrm{b} *$ Koj deto iska, da go vzeme. who that want-3sg Mod it-ClAcc take-3sg 'Whoever wants whatever, let him take it'

c. Koj kădeto iska, tam da otide. who where want-3sg there Mod go-3sg

lit. 'Whoever wants [to go] wherever, let him go there'

d. *Koj deto iska, tam da otide. ${ }^{5} \quad$ (Rudin 1986:132, ex. (20d)) who that want-3sg, there Mod go-3sg

lit. 'Whoever wants [to go] wherever, let him go there'

Rudin concludes that deto appears in typical C positions according to selection requirements (cf. also Penčev, 1998:120). Building up on these observations, I will consider deto a complementizer. ${ }^{6}$

\subsection{Pronominal resumption in deto-relatives}

The case-deficiency of deto can be compensated for by a resumptive pronoun agreeing in gender and number with the head of the relative clause and spelling out the case of the relative clause internal gap. According to Penčev (1998),

\footnotetext{
${ }^{4}$ Rudin (1986:130) explicitly mentions that the properties of deto do not stem from its adverbial nature, since it is found in all contexts where a wh-relative (nominal or adjectival) would be found but it would have to agree with the NP head.

${ }^{5}$ As pointed out by an anonymous reviewer, deto is not available in free relatives, cf. (i) below, except in contexts where it substitutes for the locative wh-adverbial kădeto 'where', cf. (ii):

(i) *Šte kupja kakvoto/*deto $\mathrm{mi}$ kažeš.

will buy-1sg whatever/that me-CIDat tell-2sg

'I will buy whatever you tell me to buy'

(ii) Namiraš si zlato, deto/kădeto potărsiš. (Ivajlo Petrov, 1978:161, www.hf.ntnu.no/hf/adm/forskning/prosjekter)

find-2sg self-ClDat gold where search-2sg

'You can find gold wherever you search for it'

${ }^{6}$ In recent work on English that Kayne (2008) suggests that all complementizers are in fact relative pronouns, hence possibly phrases. Cf. also Koopman and Sportiche (2008) on que/qui in French as weak relative pronouns. Such a proposal might reopen the old question of whether the invariable marker is a subordinating conjunction, i.e. a complementizer, or a relative pronoun. This issue, highly relevant for South Slavic where the two "forms" are often morphologically identical (see for example the discussion in van der Auwera and Kučanda (1985) on Serbo-Croatian što 'that'), will be left for future exploration.
} 
a resumptive pronoun is necessary in all deto-relatives, apart from those in which the resumptive would correspond to a non-embedded Nominative subject, which is always non-clitic. ${ }^{7} \mathrm{Cf}$. (7):

(7) *čovekăt deto $_{\text { toj }}$ govoreše s tebe...

(Penčev 1998:120) man-the that he talked-3sg with you

'the man that was talking to you'

With respect to internal argument positions, the resumptive pronoun can show up as a clitic or non-clitic, and the choice between the two seems to be governed by the following descriptive generalization: wherever a clitic is available, the corresponding non-clitic is excluded. See the contrast in (8) which illustrates indirect object resumption. ${ }^{8}$ Whenever a clitic is unavailable, a non-clitic becomes the only option: all prepositional objects are necessarily resumed by a non-clitic pronoun preceded by the preposition. This is shown by $(9 \mathrm{a}, \mathrm{b})$ :

a. čovekăt, deto mu razkazax istorijata

man-the that him-ClDat told-1sg story-the

lit. 'the man that I told him the story'

b. *čovekăt, deto razkazax istorijata na nego

man-the that told-1sg story-the to him

lit. 'the man that I told the story to him'

(9) a. momčeto, deto govorix *(za nego).

boy-the that talked-1sg about him

'the boy that I talked about'

b. kolata, deto tja sleze *(ot neja)

car-the that she got-out-3sg from her

(Penčev 1998:120)

'the car that she got out of'

As regards resumptives realized as a clitic, Rudin (1986:35f) observes that sometimes they are obligatory and sometimes optional in deto-relatives (cf. also Maslov, 1982:385). Upon closer examination it turns out that dative clitics, whether possessor or indirect object clitics, are obligatory, while accusative ones are optional. This asymmetry, illustrated by the contrast between (10a,b) and (10c), shows up only in restrictive deto RCs. In non-restrictive RCs, on the other hand, all resumptive clitics are obligatory, regardless of their syntactic function. See (11):

(10) a. Tova e čovekăt, deto Ivan kupi kăštata *(mu).

this is man-the that Ivan bought-3sg house-the him-ClDat

'This is the man whose house Ivan bought'

b. Tova e čovekăt, deto $*(\mathbf{m u}) \quad$ govorix $\quad$ za teb.

this is man-the that him-ClDat talked-1sg about you

'This is the man that I talked to about you'

c. Taja pola săm ja kupila ot nagradite, deto mi (gi) dadoxa

this skirt am her-ClAcc bought-prt-fem from awards-the that me-ClDat them-ClAcc gave-3pl

'This skirt I bought with the bonus that they gave me.'

(11) a. Tova e Ivan, $\operatorname{deto}^{*}(\mathbf{m u})$ govorix za teb.

this is Ivan that him-ClDat talked-1sg about you

'This is Ivan, whom I talked to about you'

b. Tova momče, $\operatorname{deto}^{*}(\mathbf{g o}) \quad$ običaš, njama da se oženi za tebe.

this boy that him-ClAcc love-2sg will-not Mod refl marry-3sg for you

'This boyfriend of yours, whom you love, is not going to marry you'

\footnotetext{
${ }^{7}$ The absolute ban on overt Nominative resumptives is of a more general nature, referred to in McCloskey (1990, 2006) as the Highest Subject Restriction and shared by a wide variety of languages (cf. Aoun and Li, 1990; Shlonsky, 1992; Lavine, 2003; Salzmann, 2006, a.o.). I will not pursue this issue further and will simply assume that in such cases an obligatory null resumptive appears in subject position. The idea is plausible, given that many of the languages which share the Highest Subject Restriction are pro-drop, although it is not at all clear what antilocality property of overt pronouns forces pro to be obligatory (see Borer, 1984, and McCloskey's 1990 A'-disjointness requirement). See also the discussion in Boeckx (2003:83ff).

${ }^{8}$ The same pattern of distribution holds for non-relative contexts as well.
} 
In what follows, I will not discuss non-restrictive RCs or the issue of the obligatory presence of a clitic in such relatives. I just want to point out that the facts in (10)-(11) accord with Bianchi's (2004:80) empirical generalization paraphrased here in (12):

(12) If a language allows for resumptive pronouns in restrictive RCs, this language should also allow for resumptive pronouns in non-restrictive RCs. ${ }^{9}$

As it is still unclear what syntactic properties underlie the implicational relation expressed in (12), in this paper (sections 3.2,4) I will set myself a more limited goal: to look at the distribution of accusative resumptive clitics in restrictive deto-relatives, and to show that the optionality of the clitic (as in, e.g. (10c) above) is only apparent, in the sense that structures containing a resumptive clitic involve a different derivation as compared to those not containing such a clitic. I will have nothing to say about the semantic/pragmatic conditions which call for one or the other type of structure.

As for dative clitics, I will assume that their obligatoriness depends on an orthogonal factor, namely the need to recover the preposition of the missing indirect or possessor object. (Both require a prepositional phrase, na 'to' DP, when expressing a full-fledged argument.) This effect might be attributed to a principle such as the one in (13), from Bianchi (2004:96):

(13) Inherent case must be spelled out.

A number of authors have noted that (13) is correct, at least for Slavic, in that a resumptive pronoun is obligatory whenever an oblique position bearing inherent Case is relativized. See for example Pesetsky (1998) for Polish and Russian, Toman (1998) for Czech, and Lavine (2003) for Slavic more generally. Similar observations have been made for other languages (e.g. Greek, Alexopoulou, 2006). Working in an OT framework, Pesetsky (1998) proposes that oblique Cases need "phonetic support" since they are visible for the Recoverability condition. Hence, they block the application of the lower-ranked principle Silent $t$, which bans pronunciation of silent copies. This approach provides a unitary account of all the cases involving an oblique object in Bulgarian, such as possessors and indirect objects, which in Bulgarian are expressed as a PP. Other PP objects such as those in (9) pattern with indirect objects in that they too need to be expressed overtly in order for the preposition to be recovered. Since preposition stranding is disallowed in Bulgarian, the obligatory nature of resumptives in PPs can be explained as a last resort strategy that prevents a locality violation. ${ }^{10}$

As far as structural Cases in resumptive relatives are concerned, there seems to be much richer cross-linguistic variation. This is especially true for RCs with invariable complementizers (Boeckx, 2003). For example, Swiss German does not allow accusative resumptives (Salzmann, 2006), but a number of Slavic languages seem to require them, as discussed in Lavine (2003) on the basis of Polish and Ukrainian. Greek and Albanian also force obligatory resumption of direct objects in their respective that relatives, provided the head of the RC is indefinite and/or topicalized (Stavrou, 1984; Alexiadou and Anagnostopoulou, 1999; Kallulli, 2008, a.o.). So, the second part of Pesetsky's proposal, namely that structural case is "recoverable" and therefore must not be resumed, appears not to be

\footnotetext{
${ }^{9}$ Bianchi discusses a third type of relative clause, which she calls, following Grosu and Landman (1998), a 'maximalizing relative' (also known as 'amount relative', in Carlson's, 1977 terms). In the latter type, the relativized "head" does not denote a set of individuals, but a set of amounts. Resumptive clitics do not seem to be possible here, as can be seen by the two examples given in (i):

(i) a. Săžaljavam za vremeto, deto ti (*go) izgubix.

regret-1sg about time-the that you-ClDat it-ClAcc wasted-1sg

'I am sorry about the time I wasted on you.'

b. Vidjax tova, deto trjabvaše da (*go) vidja.

saw-1sg this that had Mod it-ClAcc see-1sg

'I saw what I had to see.'

If the judgements in (i) are correct, as I believe they are, then Bulgarian patterns with Italian, Hebrew, Brazilian Portuguese and Irish in disallowing a resumptive clitic in maximalizing relatives (Bianchi, 2004:79). These relatives are briefly discussed in the next section, although I will not consider here their differences with the other restrictive relatives. For finer-grained distinctions within maximalizing relatives, the reader is referred to McNally (2008) and Herdan (2008) for some Slavic and Balkan languages. See also the discussion in Aoun and Li (2003:107ff).

${ }^{10}$ On the basis of data from Greek, Alexopoulou (2006) argues that obligatory resumption with PP objects is due to the failure of identification of the non-argument's phi-features. Resumption thus arises as a last resort mechanism which ensures the identification of such phrases at LF.
} 
true (see also Lavine, 2003). Nevertheless it is important to find out for each language what parameters determine the overt realization of the accusative feature as a resumptive pronoun. These parameters might well turn out to be of a pragmatic nature such as specificity, D-linking, or presupposition of existence. ${ }^{11}$ However, in what follows, I will not discuss this issue further but will focus on the structural effects of resumption or absence thereof and the implications of these two distinct configurations for the derivation of RCs.

\section{Towards an analysis of deto-relatives: raising, matching or both?}

\subsection{Reconstruction effects}

The absence vs. presence of an accusative clitic in restrictive RCs seems to correlate with the two known derivations of RCs: Head raising (Brame, 1968; Schachter, 1973; Vergnaud, 1974; Kayne, 1994; Bianchi, 1999) and matching (Chomsky, 1977; Ross, 1967, and its more recent version in Sauerland, 1998, 1999; cf. also Salzmann, 2006). For a particularly clear discussion of the comparison between the two analyses the reader is referred to Aoun and Li (2003:100-107).

The raising analysis has different variants, but the common idea sketched in (14) is that the Head of the RC is merged inside the RC and subsequently raises to $\mathrm{Spec}, \mathrm{CP}$ (or to a higher specifier). Thus, a direct chain relationship is established between the overt Head and its trace (the unpronounced copy) inside the RC:

The Raising analysis (Kayne 1994)

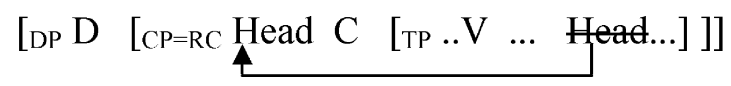

According to the matching analysis, (15), on the other hand, there are two Heads, an external and an internal one. The external Head is the relativized NP, i.e. the Head of the RC which gets connected to the internal Head (the gap inside the $\mathrm{RC}$ ) possibly in the form of an empty operator (Op) raising from the gap position to Spec,CP. In other words, no direct transformational relationship exists between the overt Head NP and the RC internal position. Additionally, the classical matching analysis makes use of adjunction of the RC to the Head in order to ensure that the two enter into a predication relation:

The Matching analysis (Ross, 1967; Chomsky, 1977; Sauerland, 1998; Salzmann, 2006, a.o.)

$\left[\mathrm{NP} / \mathrm{DP}\left[\mathrm{NP} / \mathrm{DP}\left[\mathrm{CP}\right.\right.\right.$ Op $\left.\left.\mathrm{p}_{\mathrm{i}} \mathrm{C} \quad\left[\mathrm{IP} . . \mathrm{V} . . \mathrm{t}_{\mathrm{i}} \ldots ..\right]\right]\right]$

Crucial arguments in favour of the raising analysis come from RCs with amount readings and idiom chunks in Head position. Consider (16a) from English (taken from Sauerland, 1998:68), and (16b) which provides an equivalent example from Bulgarian:

(16) a. No linguist would read the many books that John should prepare many books for the exam.

b. Nito edin lingvist ne bi pročel knigite, deto Ivan trjabva da podgotvi knigi not one linguist not would read-prt books-the that Ivan must Mod prepare-3sg

za izpita.

for exam-the

'No single linguist would read [all] the books that Ivan must prepare for the exam'

The interpretation of (16b) alongside that of (16a) is that linguists would not read the number of books that Ivan has to prepare for the exam. This interpretation instantiates the so-called 'amount reading' ('identity of quantity') and, as argued since Carlson (1977) (see also Sauerland, 1998; Grosu and Landman, 1998), requires that (part of) the overt Head (knigi in (16b)) be reconstructed to a position within the RC, in which the covert amount quantifier can be

\footnotetext{
${ }^{11}$ Bošković (in press) discusses the obligatory presence of a direct object clitic in Serbo-Croatian što 'that' relatives and in corresponding detorelatives, and suggests that the factors triggering resumption are related to animacy and/or specificity, which he analyzes as effects of differential object marking (DOM), also instantiated by 'clitic doubling' in various languages. As the author recognizes, the exact factors governing DOM may not be the same and are in need of a better understanding. For a discussion of animacy effects under resumption in other Slavic languages, see Lavine (2003).
} 
interpreted also in the scope of the modal trjabva 'must'. Reconstruction then can be taken as direct evidence that deto RCs may involve raising of the Head. ${ }^{12}$

A second argument in favour of the raising analysis comes from idiom chunks, illustrated here with the idiom chunk okazvam natisk 'put pressure' in (17a). It is well-known (since Brame, 1968) that idiom chunks force reconstruction too, since the relativized part of the idiom must be reunited at LF with the rest of the idiom for interpretation (see also Schachter, 1973; Bianchi, 1999:43-45; Sauerland, 1999 for a relevant discussion regarding the strength of this argument). Since the idiomatic reading is preserved in the relative clause in (17b) the overt Head natisk 'pressure' must have undergone reconstruction inside the RC. The example thus provides another piece of evidence that Head raising has applied $^{13}$ :

(17) a. Evropa okazva natisk na Bălgarija zaradi OMO Ilinden.

Europe exert-3sg pressure on Bulgaria because-of OMO Ilinden

'Europe puts pressure on Bulgaria because of OMO Ilinden' 14

b. Natiskăt, deto Evropa okazva natisk na Bălgarija zaradi OMO Ilinden, pressure-the-SUBJ that Europe exert-3sg on Bulgaria because-of OMO Ilinden e nepravomeren.

is illegal

'The pressure that Europe puts on Bulgaria because of OMO Ilinden is illegal'

Reconstruction effects in deto-relatives are also detectable in the context of anaphor (plus pronominal) binding illustrated in (18). In this case reconstruction is driven by the need to license the reflexive anaphor $s i$ 'her' contained in the relative Head but, since at LF the reconstructed position is under the scope of the quantifier vsjaka 'every', the reflexive also receives a bound variable (distributive) reading:

(18) Snimkite na deteto si, deto vsjaka majka nosi snimkina si $\mathrm{v}$ portmoneto si pictures-the of child-the her-refl, that every mother carry-3sg in purse-the her-refl

'the pictures of her child that every mother carries in her purse.'

Bulgarian deto-relatives also show reconstruction effects for scope purposes, yet another indication that reconstruction takes place (Bianchi, 1999:45-46, 122-123; Aoun and Li, 2003:98-99):

(19) a. Vseki režisjor trjabva da snima dva/\#dvata filma v Sozopol.

Each director must Mod shoot-3sg two/two-the films in Sozopol.

'Each director must shoot two films in Sozopol' $(\forall>2)$

b. Dvata filma, deto vseki režisjor trjabva da snima v Sozopol, šte učastvat

two-the films that each director must Mod shoot-3sg in Sozopol will take-part-3pl

văv festivalnata programa.

in festival-the program

'The two films that each director has to shoot in Sozopol, will participate in the festival program' $(\forall>2)$

In (19a) the indefinite object QP dva filma 'two films' is in the scope of the universally quantified subject and the quantifier two can only get a narrow scope reading with respect to each. This gives rise to a distributive interpretation according to which each director must shoot two different films. The interpretation survives when the object QP is relativized, as in (19b), and under the plausible assumption that the definiteness feature of the relativized Head is not

\footnotetext{
${ }_{12}$ This seems true for other Slavic languages as well. See in particular Szczegielniak (2005:17) for Polish and Russian complementizer relatives.

${ }^{13}$ Additionally, the examples in (17) provide an argument in favour of Kayne's (1994) original suggestion that the raising derivation of relative clauses must contain an external D (Bianchi, 1999:43-48), cf. (14) above. As can be seen from the ungrammaticality of (i) below, the nominal part of the idiom chunk must not bear the definite article, which in Bulgarian is postposed and has the shape $-a$ for masculine nouns in object position. This indicates that in the text example (17b), the definite article - $\breve{a t}$ (for masculine nouns in subject position) appearing on the relativized Head cannot have been carried along with it from inside the relative clause but must have its source in the external D position:

(i) *Evropa okazva natiska na Bălgarija zaradi OMO Ilinden.

Europe exerts pressure-the-DO on Bulgaria because-of OMO Ilinden

${ }^{14}$ Odrinsko-makedonska organizacija Ilinden, a political organization in Bulgaria.
} 
carried along with it (or else, (19a) becomes incoherent) but comes from the external D merged outside of CP (see footnote 13), the preservation of scope in examples like (19b) indicates that QP has been raised from the object position inside the relative clause.

To summarize, so far we have seen four pieces of evidence that deto-relatives can involve reconstruction effects: amount readings, idiom chunk interpretation, binding, and scope. Given the analysis of reconstruction as diagnostic for the presence of movement (Chomsky, 1993) and the conclusion that such an approach constitutes an argument in favour of the Head raising analysis (Kayne, 1994:87), the data examined so far are naturally interpreted as evidence that complementizer relatives in Bulgarian can exploit a movement strategy. Within the copy theory of Chomsky (1993) the reconstruction facts we saw in (16)-(19) above fall out naturally, since the trace left behind by overt movement is a copy of the moved element which is unpronounced at PF but present at LF, thus allowing the higher copy of the chain (the "overt" Head) to be interpreted in the position of the lower copy (the trace/gap inside the RC).

\subsection{Reconstruction and resumption}

This subsection will examine reconstruction effects in relative structures involving a resumptive clitic and will discuss the problems such constructions present for the raising analysis. The following sentences demonstrate that both the amount reading and the idiomatic interpretation are lost when the RC contains an accusative (direct object) clitic:

(20) a. Nito edin lingvist ne bi pročel knigite, deto Ivan trjabva da gi not one linguist not would read-prt-m books-the that Ivan must Mod them-ClAcc podgotvi za izpita. prepare-3sg for exam-the 'No single linguist would read the books that Ivan must prepare for the exam'

b. *Natiskăt, deto Evropa go okazva natisk na Bălgarija zaradi OMO Ilinden, pressure-the that Europe it-ClAcc exert-3sg on Bulgaria because-of OMO Ilinden e nepravomeren.

is illegal

'The pressure that Europe puts on Bulgaria because of OMO Ilinden is illegal'

What (20a) means is that there is a specific set of books which Ivan has to prepare for the exam and that no linguist would like to read the books in this set. This 'identity of substance' interpretation, being the only one admissible, implies that the resumptive clitic blocks the possibility for reconstruction of the relative Head, hence the latter cannot get the 'amount' reading. Absence of reconstruction is also the reason for the ungrammaticality of (20b), since the relevant part of the idiom chunk can no longer be paired with the rest of the idiom, as opposed to (17b) above. The examples in (20) thus provide an argument against movement and consequently against the raising derivation of resumptive deto-relatives. See Szczegielniak (2005:22ff) for a discussion of analogous data and conclusions based on other Slavic languages (Polish and Russian).

A resumptive clitic also blocks anaphor/pronominal binding, cf. (21a), as well as scope reconstruction, cf. (21b). In (21a) the reflexive anaphor $s i$ 'her' contained in the relativized Head can no longer be bound by the relative clause internal quantifier, also rendering unavailable the bound variable reading we saw possible in (18), the "raising" analog of (21a). The distributive reading is also unavailable in (21b); in contrast to (19b), the relativized Head can only have a wide scope reading with respect to the relative clause internal quantifier, leading to an incoherent interpretation:

(21) a. *snimkata na deteto si, deto vsjaka majka ja nosi $\quad \mathrm{v}$ portmoneto $\mathrm{si}, \ldots$ picture-the of child-the her-refl that every mother her-ClAcc carry-3sg in purse-the her-refl 'the picture of her child that every mother carries [it] in her purse...'

b. \#Dvata filma, deto vseki režisjor trjabva da gi snima v Sozopol, two-the films that each director must Mod them-ClAcc shoot-3sg in Sozopol šte učastvat văv festivalnata programa. will take-part-3pl in festival-the program

'The two films that each director has to shoot in Sozopol, will participate in the festival program' $(* \forall>2 ; 2>\forall)$ 
In the presence of a resumptive clitic the Head cannot reconstruct inside the RC.

Another argument against the raising analysis comes from the absence of Principle $\mathrm{C}$ effects in resumptive relatives. Consider (22) where the R-expression (Ivan) within the Head of RC is coreferent with the pronoun toj 'he' inside the RC. The raising analysis would predict a Condition $\mathrm{C}$ violation since under reconstruction the copy of the R-expression inside the RC would end up being c-commanded by the coindexed pronoun. The fact however that Condition $\mathrm{C}$ is obviated in (22) shows that no reconstruction, hence no movement is involved in such cases:

(22) Onazi snimka na $\operatorname{Ivan}_{i}$, deto $_{\text {toj }}$ ja

xaresva mnogo, e naistina xubava.

that picture of Ivan that he her-ClAcc like-3sg a lot is really nice

'That picture of Ivan that he likes [it] a lot is really nice'

As discussed in Sauerland (1998:68, 2003), absence of Condition C effects is a major challenge to the raising analysis of relative structures, especially given the contrast with $w h$-movement where Condition C effects systematically show up. ${ }^{15}$ Sauerland further argues, following in the steps of Carlson (1977), that at least for those cases where reconstruction/movement is unavailable, the matching analysis must be made available since under the latter (cf. (15)), the relativized Head is generated externally rather than being moved from inside the relative clause. The data in (20)-(22) thus provide evidence that a matching structure is available in deto-relatives, given the absence of properties such as amount readings, idiom chunks, anaphor/pronominal binding, narrow scope readings, and Condition $\mathrm{C}$ effects under resumption.

Note however that the lack of Condition C effects in deto-relatives is independent from resumption, since alongside (22), which contains the resumptive clitic $j a$ 'her', referring to the picture of Ivan, (23) is also possible with no resumptive clitic and no Principle $\mathrm{C}$ effect either:

(23) Onazi snimka na $\operatorname{Ivan}_{\mathrm{i}}$, deto toj $\mathrm{j}_{\mathrm{i}}$ xaresva mnogo, e naistina xubava.

that picture of Ivan that he like-3sg a lot is really nice

'That picture of Ivan that he likes a lot is really nice'

The systematic contrast between "raising" relatives and resumptive relatives seems to break down only with respect to Condition C. However, the data can be interpreted as an indication that gap relatives are "structurally ambiguous", i.e. compatible with both raising and matching, depending on factors which force one or the other derivation. To see this, consider the two examples in (24) constructed on the basis of the test proposed by Sauerland (1998:71) for English that relatives. In (24a) reconstruction of the relativized Head which contains an R-expression is forced by the idiomatic interpretation; in (24b) this happens for variable binding. Both examples are ruled out as a Condition $\mathrm{C}$ violation since the reconstructed R-expression finds itself in the domain of a coreferent pronoun. Therefore, Principle $\mathrm{C}$ effects re-emerge once a raising derivation is enforced:

\footnotetext{
${ }^{15}$ This is true for Bulgarian as well. As illustrated by the minimal pair in (i)-(ii), Condition C effects are present in wh-questions, as opposed to Heads of relative clauses. Note that (i) is ungrammatical irrespective of whether a resumptive clitic is present or not, indicating that a movement configuration is established under resumption with the clitic acting as a "double" of the wh-phrase moving to Spec,CP. Since outside of Condition C contexts resumptive clitics are available in d-linked wh-questions in Bulgarian, the ungrammaticality of (i), as opposed to (ii), must be explained as reflecting a difference between relative clause formation and other cases involving movement:

(i). *Koja snimka na $\operatorname{Ivan}_{\mathrm{ij}}$ toj $_{i}$ (ja) xaresva $\mathrm{t}_{j}$ mnogo? which picture of Ivan he her-ClAcc like-3sg a lot 'Which picture of Ivan does he like a lot?'

(ii) Koja e snimkata na $\operatorname{Ivan}_{\mathrm{i}}$ deto toj $\mathrm{j}_{\mathrm{i}}(\mathrm{ja})$ xaresva mnogo? which is picture-the of Ivan that he her-ClAcc like-3sg a lot 'Which is the picture of Ivan that he likes a lot?'
} 
(24) a. *Natiskăt na prezidenta $\mathrm{i}_{\mathrm{i}}$, deto toj $\mathrm{j}_{\mathrm{i}}$ okazva natisk na prezidenta vărxu pravitelstvoto pressure of president-the that he exert-3sg e nepravomeren. is illegal

b. * Onezi pisma na Ivan do neja $_{i}$, deto toj $j_{j}$ kaza na vsjaka žena $a_{i}$ da izgori pisma those letters of John to her that he said-3sg to every woman Mod burn-3sg do neja, bjaxa publikuvani were published-pl

Given (24), it follows that the absence of a Condition C violation in (23) cannot be explained on the basis of the raising analysis, suggesting that a matching analysis should also be available for the derivation of gap relatives.

As for resumptive relatives, a raising derivation cannot be enforced in contexts parallel to (24), because, as already pointed out (in relation to the ungrammaticality of (21)-(22)), a resumptive clitic is systematically excluded wherever reconstruction is required to take place. I interpret this as an indication that resumptive relatives are compatible with a matching derivation only. ${ }^{16}$

Aoun et al. (2001) have shown for Lebanese Arabic that the possibility for reconstruction in resumptive relatives correlates with island sensitivity: resumptives not showing reconstruction effects can find themselves inside strong islands (the term they suggest is "true" resumption), while those which do show reconstruction effects can only appear outside islands ("apparent" resumption). If reconstruction is indeed a diagnostic for movement, it follows that only the latter type of resumptive is formed by movement. "True" resumption, on the other hand, does not involve movement, i.e. there is no chain relation between the resumptive and the Operator, so it is a strategy available only in island contexts, from which movement is impossible. The examples in (25) from Bulgarian where a resumptive clitic appears obligatorily in a complex NP island, an adjunct island, and a factive island, respectively, show that it is island insensitive and hence can be said to belong to the class of "true" resumptives, for which Aoun et al. propose a basegeneration analysis. (See Rudin, 1986:142 for a more extensive discussion of the lack of island effects in resumptive deto-relatives):

(25) a. Tova e edin film, deto vsicki, koito sa *(go) gledali, mnogo go xaresvat. this is a film that all who are-3pl it-ClAcc seen-prt-pl a-lot it-ClAcc like-3pl 'This is a film that all who have seen it like it a lot'

b. ..čovekăt, deto tja se uplaši, kato *(go) vidja da izliza ot stajata.. man-the that she refl got-scared-3sg when him-ClAcc saw-3sg Mod leave-3sg from room-the lit. 'the man that she got scared when she saw him leaving the room'

c. Vidjax edna kniga, deto faktăt, če *(ja) prodavat, me iznenada. (Rudin 1986:142, ex. (42a)) saw-1sg a book that fact-the that her-ClAcc sell-3pl me-ClAcc surprised-3sg

'I saw a book that the fact that they're selling it surprised me'

However, unlike "true" resumptives in Lebanese Arabic which are only found within islands (Aoun and Choueiri, 1997; Aoun et al., 2001), and can thus be seen as some kind of "intrusive"/last resort element (Sells, 1984; Boeckx, 2003:148f)

\footnotetext{
${ }^{16}$ Additionally, resumptive relatives do not show WCO effects, as can be seen by (i):

(i) Tova e momčeto $o_{i}$, deto majka $\mathrm{mu}_{\mathrm{i}} \operatorname{mnogo} *(\mathrm{go})_{\mathrm{i}}$ običa.

this is boy-the that mother his much him-ClAcc love-3sg

'This is the boy who his mother loves a lot'

Note that the absence of a crossing effect under resumption shows up also when the relative Head is a quantificational expression, see (ii), so Lasnik and Stowell's (1991) explanation of WCO as due to the quantificational status of the operator, cannot apply here:

(ii) Ne vsički, deto misljat, če majka im *(gi) običa, sa štastlivi. not all that think-3pl that mother their them-ClAcc love-3sg are happy-pl

'Not all people that think their mother loves them are happy'

If WCO depends on the type of 'variable' (pronominal vs. gap), the presence of WCO effects in the corresponding structures containing a gap strengthens the conclusion that gap relatives involve a quantificational structure, as opposed to resumptive relatives, which do not.
} 
used to amnesty an island violation (Kroch, 1981), Bulgarian "true" resumptives, I suggest, can occur in all contexts involving matching. The right way to phrase this distinction seems to be that the antecedent-resumptive relation in Bulgarian deto-relatives may cross an island boundary, while in Lebanese Arabic it must cross an island boundary (Aoun et al., 2001:394). This distinction will turn out to have consequences for the derivation of resumptive relatives in Bulgarian to be discussed in section 4.5.

From a cross-linguistic point of view, however, lack of reconstruction effects and island insensitivity do not appear to always correlate, as they do in Bulgarian. Depending on the language, resumptive pronouns in complementizer relatives can show or not show reconstruction effects and can be island sensitive or not, the two dimensions apparently being independent from one another. For example, reconstruction effects are present in Hebrew and Irish resumptive relatives but the resumptive pronoun is insensitive to islands ${ }^{17}$ (Shlonsky, 1992; McCloskey, 1990, 2002). Just the opposite seems true for Scottish Gaelic (Adger and Ramchand, 2005; Boeckx, 2003:111), Greek (Alexopoulou, 2006), and Romanian (Dobrovie-Sorin, 1990) in that these languages exhibit no reconstruction effects under resumption but the resumptive pronoun is island sensitive. This cross-linguistic difference is apparently found even within one and the same language. A case in point is Lebanese Arabic where reconstruction effects can be detected in definite resumptive relatives (provided that they do not occur in an island context), although not in indefinite relatives and in definite relatives in which the resumptive appears inside an island (Aoun and Choueiri, 1997; Aoun et al., 2001).

The tension between (non-)reconstruction and island (in)sensitivity obviously cannot be resolved be relying exclusively on a movement or a non-movement derivation. The base-generation type of approaches to resumption (positing some sort of Agree relationship not followed by Move) faces the problem of accounting simultaneously for reconstruction effects and for the possibility that in some languages resumptives are island sensitive. Conversely, movement type approaches (positing Agree followed by Move) fail to predict absence of reconstruction effects (as in e.g. the 'big-DP' approach of Boeckx, 2003) or insensitivity to islands (as in the resumptives-as-spelled-out-traces approach of Pesetsky, 1998).

On the basis of the observations made above from Bulgarian, we can suggest that the tension between the two dimensions can be "resolved" by assuming that languages may exploit either raising or matching in the derivation of their RCs. Reconstruction implies that raising has applied (whether the structure contains a gap, as in Bulgarian, or a resumptive, as in languages where reconstruction effects are found also under resumption). Island effects on the other hand do not necessarily imply a raising derivation; they may also be found under matching. In other words, what I propose basically is that the matching derivation comes in two varieties: one which involves movement internal to the relative clause and another one which involves merging of an empty Operator, as in standard (base-generation) approaches to resumption not showing locality effects (McCloskey, 1990, 2002; Shlonsky, 1992; Suñer, 1998; Rouveret, 2002, a.o.). In fact, Aoun and Li (2003) try to capture this tripartite distinction as observed in English, Lebanese Arabic and Chinese, by proposing that UG makes the following strategies available for the derivation of relative constructions: (a) Head raising (promotion analysis); (b) wh-operator movement (matching analysis); and (c) direct base-generation (no-movement analysis). ${ }^{18}$ In what follows, I will continue to treat (c) as a subcase of the matching derivation (b).

To summarize, in this subsection we have seen evidence, based on the absence of reconstruction effects, in favour of analyzing a subset of deto-relatives (gap relatives and relatives containing a resumptive element), as compatible with a matching rather than a raising derivation. This raises the question of how to accommodate in a structural way this latter evidence with the evidence presented in section 3.1. which pointed towards full scale reconstruction effects (amount readings, idiom interpretation, pronominal and anaphor binding, narrow scope and Principle $\mathrm{C}$ effects) and hence to the necessity of a raising analysis. On a descriptive level, a natural solution would be to assume that depending on the type of Head, one or the other derivation is forced, a proposal which I

\footnotetext{
${ }^{17}$ Welsh (indirect) relatives, according to Rouveret (2002, 2007), also show reconstruction effects with respect to pronominal binding and anaphor binding, although not with respect to Principle C. The absence of a Principle $\mathrm{C}$ effect could be accounted for if a matching derivation is adopted for such cases. This is what Rouveret (2007) eventually seems to propose but from a different perspective arguing for a non-movement analysis of Welsh resumption. It is to be expected that in Welsh too, should something force reconstruction, a Principle C violation would re-emerge, as it does in English and Bulgarian. In fact the scope phenomenon reported in Rouveret (2002) whereby in (non-specificational) resumptive relatives displaying multiple individual (distributive) readings Principle $\mathrm{C}$ effects do show up as a result of a forced reconstruction seems to confirm this expectation.

${ }^{18}$ According to Aoun and Li (2003:114), strategy (b) applies to wh-relatives (as opposed to non-wh-relatives, which exploit strategy (a)) but I believe it can be generalized to also cover matching relatives involving relative clause internal movement to be discussed below.
} 
will develop in the next section, following Sauerland's (1998) original insight and Cinque's (2003, 2008) theoretical elaboration of it.

\section{Towards a unified analysis of deto-relatives}

\subsection{Raising AND matching}

The goal of this section is to propose that the two derivations we saw above can be accommodated in a unitary structure without abandoning the idea of antisymmetry (for which the classical matching analysis is problematic given the necessary adoption of a rightward adjunction structure). I will argue that this goal can be achieved under Cinque's (2003) proposal, which states crucially that the RC is not adjoined to the right of the head but is merged in a specifier of the extended projection of the NP, i.e. prenominally. One conceptual argument, independent of antisymmetry considerations, in favour of such a prenominal Merge position may come from the fact that RCs, much like adjectives, are modifiers of the NP, actually of the extended projection of the NP. If RCs are a sort of "syntactic adjective", it is reasonable to suppose that they too are merged prenominally and enter the hierarchy of the NP's functional projections in a specific position. According to Cinque, another consideration, of a more general conceptual-empirical type, is "the pervasive left-right asymmetry found cross-linguistically" (Cinque, 2009), in the sense that generally, there is a unique (unmarked) order of complements, modifiers and functional heads when the latter occur to the left of a lexical head $(\mathrm{N}, \mathrm{V}$, etc.), while when they occur to the right of the head, there exist at least two possibilities: either the same order as the one found to the left of the head, or its mirror image. This has led him to conclude that constituents found to the right of a head, including RCs in languages where they appear postnominally, are possibly never merged there, but come to be there as a consequence of the head moving leftward past them.

Cinque argues that the position of Merge of finite relative clauses is above the Numeral (Num) and the (various types of) Adjectives, but below Universal Quantifiers, Demonstratives and Definite determiners, as indicated in the hierarchy in (26) below, which in Cinque (2005) is argued to be (a fragment of) the universal Merge structure of nominal phrases:

(26) Universal Quantifier $>$ Demonstrative/Definite Determiner $>$ (finite) Relative Clause $>$ Numeral/Indefinite Determiner $>$ Adjective ... Adjective $>$ NP

In what follows, I will abstract away from the relative order of elements within the NP's extended projection since it is not relevant for the issue at hand, and will follow Cinque in using "external Head" to refer to the complex Head, modified by the RC, which contains material that has been independently shown to appear below the RC in (26), i.e. Numerals/Indefinite Determiners, Adjectives, and the NP.

Based on the above premises, Cinque proposes that there is a single structure underlying all types of RCs under both the raising and the matching derivations. In this structure, the RC is an IP merged as a modifier of the portion of the extended projection of the noun phrase, occupying a specifier position of that extended projection. Within the RC, there is an exact match (a full independent copy) of the external Head at the relativization site, what Cinque calls the "internal Head". See (27b) which represents the Merge structure of the relative clause in (27a). The postulation of two Heads basically follows the guidelines of the original matching analysis (cf. Chomsky, 1965; Ross, 1967) and its more elaborate recent modifications (especially Sauerland, 1998, 1999, 2003), but the structure in (27b) also incorporates the insight (of the raising analysis) that the determiner is merged outside of the union of the Head and the RC. Cinque (2008) further proposes that each copy of the Head is represented by an indefinite NP which he labels " $\mathrm{dP} " 19$ and which contains only weak determiners in the sense of Milsark (1974) (a numeral, an indefinite article, etc.).

\footnotetext{
${ }^{19}$ For arguments that the relativized Head is indefinite, see Choueiri (2002, section 3), Cinque (2008) and references therein. The empty internal D of the moved relative DP that Bianchi (1999, chapter 6) proposes (see e.g. (i)) refining Kayne's (1994) Head raising analysis could be rethought in terms of this lower indefinite head:
}

(i) $\left[\mathrm{DP}[\mathrm{D}\right.$ the $]\left[\mathrm{CP}\left[\mathrm{DP} \varnothing\right.\right.$ thing [C that [IP $\mathrm{t}_{\mathrm{DP}}$ happened ]]]]] (Bianchi, 1999:176) 
(27) a. the expensive books that John bought

(27) b.

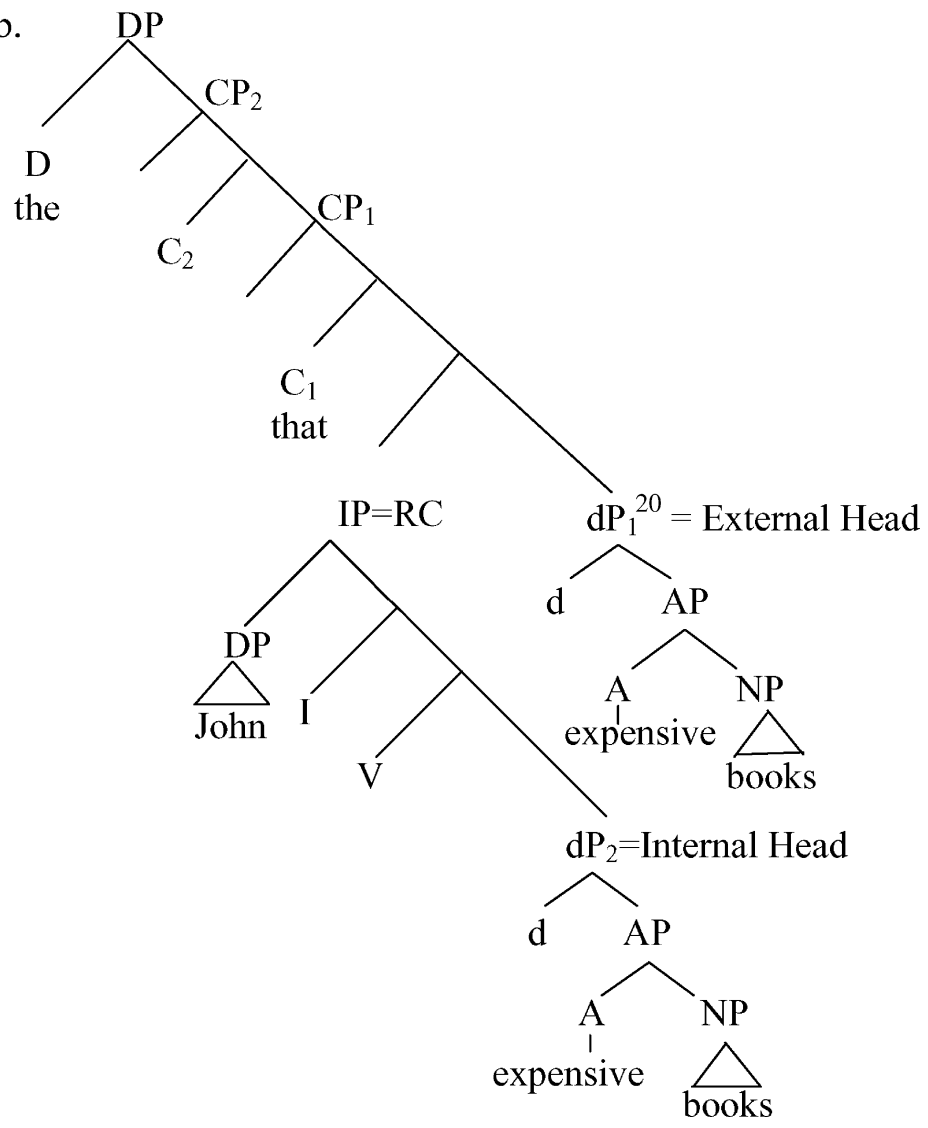

Given the structure in (27b), in a language like English or any other language with postnominal relative clauses, the formation of the overt "head" can be conceived of as resulting from a movement operation involving either the internal or the external Head or both. Essentially, these two options correspond to the raising and the matching analysis, respectively, the choice between them being driven by familiar semantic considerations which require, or block, reconstruction of the overt Head.

Turning to Bulgarian, consider for example the idiom relative clause in (17b) repeated below as (28a). The raising analysis of deto-relatives is argued here to involve raising (attraction) of the internal Head to a CP position which in (28b), the structural representation of (28a), is indicated as the specifier of the functional head where the complementizer is merged, i.e. Spec, $\mathrm{CP}_{1}{ }^{21}$ Since the internal Head comes to occupy a hierarchically higher position $\mathrm{c}$-commanding the external Head, the former can delete the latter under identity at $\mathrm{PF}^{22}$ and will thus get pronounced at Spell-out. In the structure (28b), ${ }^{23}$ as well as in all subsequent structures in the text below, only the relevant part of the example is represented and details are omitted; the PF deleted copy of the Head is shadowed in grey:

\footnotetext{
${ }^{20}$ The notations $\mathrm{dP}_{1}$ and $\mathrm{dP}_{2}$ are used only for convenience; the two copies are meant as non-distinct.

${ }^{21}$ For reasons of simplicity, I abstract away from issues relating to the Doubly-filled Comp Filter which has been claimed to be operative in Bulgarian (Rudin, 1986), as in Slavic languages more generally (Borsley, 1997; Lavine, 2003).

22 There are several ways in which such PF deletion can be conceived of but I will not dwell on this issue further. I just refer the reader to Citko (2001) and Sauerland (2003). The latter author argues that the corresponding mechanism is "relative deletion" and views it as akin to ellipsis. Under this proposal the internal Head (Op NP) gets deleted under identity with its base-generated copy, i.e. the external Head, so the mechanism of "relative deletion" is available only in matching relatives, but not in raising ones which are derived by movement of the internal Head. In Cinque's system, on the other hand, the overt Head is derived by movement in both raising and matching relatives, as we will see, so either copy of the Head can delete, depending on structural height. For the problem posed by the second occurrence of the idiom chunk in the external Head in raising structures of the type in (28b) below, see Cinque (in preparation).

${ }^{23}$ Note that $\mathrm{D}$ hosts the definite article which in Bulgarian is postposed and affixal in nature. Current analyses of the Bulgarian DP propose that the definite article is affixed to $\mathrm{N}$ already in the numeration (rather than being generated under $\mathrm{D}$ ) and either raises to or is in an Agree relation with Spec of D (see e.g. Dimitrova-Vulchanova and Giusti, 1996; Caink, 2000; Franks, 2000). I will assume that such line of reasoning is correct. Nevertheless in the structures that follow, the article will be represented under $\mathrm{D}$, in accordance with the traditional treatment of the structure of RCs.
} 
(28)

a. Natiskăt, deto Evropa okazva natisk na Bălgarija zaradi OMO Ilinden, pressure-the-SUBJ that Europe exert-3sg on Bulgaria because-of OMO Ilinden e nepravomeren.

is illegal

'The pressure that Europe puts on Bulgaria because of OMO Ilinden is illegal'

(28)

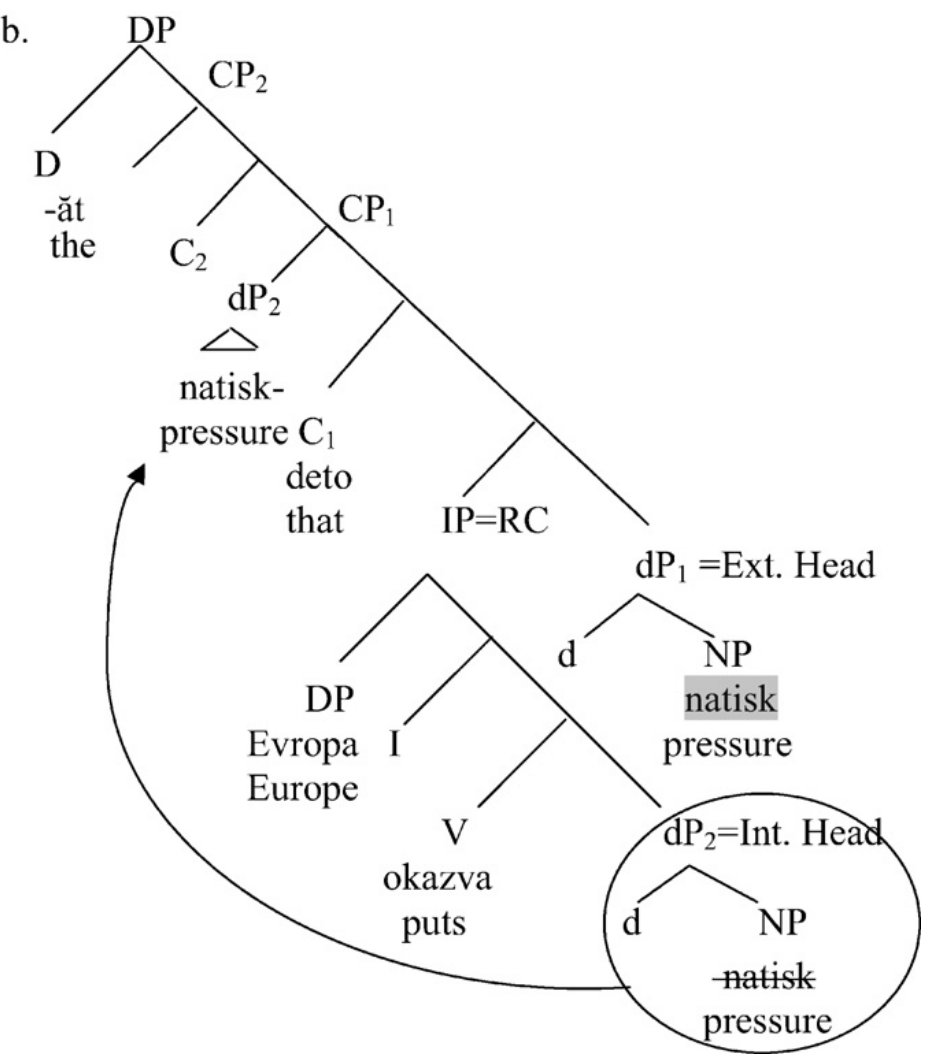

The representations in (27b) and (28b) are based on the assumption that the extended projection of the noun phrase has a richer structure than assumed by the classical analyses of relativization, containing a CP area. Bianchi (1999) too has convincingly shown that the relative clause left periphery can be accommodated under the Split CP approach of Rizzi (1997) ${ }^{24}$ Below I will present evidence from Topic and Focus placement in Bulgarian which can give us a clue about the relative order between the two CPs in (28) but for the time being we can assume that the complementizer occupies $\mathrm{C}_{1}$ and hosts the internal Head $\mathrm{dP}_{2}$ in its specifier. This type of movement may be thought of as corresponding to Chomsky's (1977) Operator movement triggered possibly by the necessity to create a representation that translates directly into an open $\lambda$-predicate entering into a predication relation with the relativized Head (Sauerland, 2003). Since movement of the internal Head leaves a copy in the position of the gap inside IP, the entire range of reconstruction effects detected above for raising relatives (see examples (16)-(19)) can be accounted for, given the direct chain relation established between the higher occurrence of the internal Head (in Spec, $\mathrm{CP}_{1}$ ) and its copy inside IP. ${ }^{25}$

Now recall our earlier conclusion based on (22)-(23) above that, unless a raising derivation is enforced, in which case a resumptive clitic is not allowed and reconstruction effects re-emerge (cf. (24) above), absence of Condition C effects in deto-relatives calls for a matching derivation. So let's see how the input structure (27b) can accommodate this derivation.

Cinque (2003, 2008, in preparation) follows the classical matching analysis in assuming that in matching relatives the "overt" Head is the external Head. However, he supposes that the external Head $\mathrm{dP}_{1}$, instead of being base

\footnotetext{
${ }^{24}$ More precisely, Bianchi (1999) has argued that the left periphery of wh-relatives involves a lower CP projection, TopP, hosting the $w h$-phrase (moved together with the NP from inside IP), and a higher CP projection, ForceP, hosting the $w$-operator on the second step of the derivation. For a tentative proposal concerning the identification and the labeling of the two CP positions in (28b), see section 4.2.

${ }^{25}$ For an alternative treatment in terms of an Op feature sharing operation (Agree) followed by EPP-driven Move see McCloskey (2002) and Rouveret (2002).
} 
generated to the left of the relative clause CP, i.e. [NP/DP NP/DP [CP relative] (cf. e.g. Sauerland, 1998; Citko, 2001; Aoun and Li, 2003), is, as shown in (27b) and (28b), that portion of the extended projection of the NP which is immediately below (is modified by) the relative clause IP merged prenominally. As will be discussed in some detail later, the external Head $\mathrm{dP}_{1}$ gets attracted to a position higher than that targeted by the internal Head $\mathrm{dP}_{2}$ in the raising derivation, namely Spec, $\mathrm{CP}_{2} \cdot{ }^{26}$ See the structural representation in (29) below. From that position $\mathrm{dP}_{1} \mathrm{c}$-commands $\mathrm{dP}_{2}$ (in $\mathrm{Spec}, \mathrm{CP}_{1}$ ) and deletes it at PF.

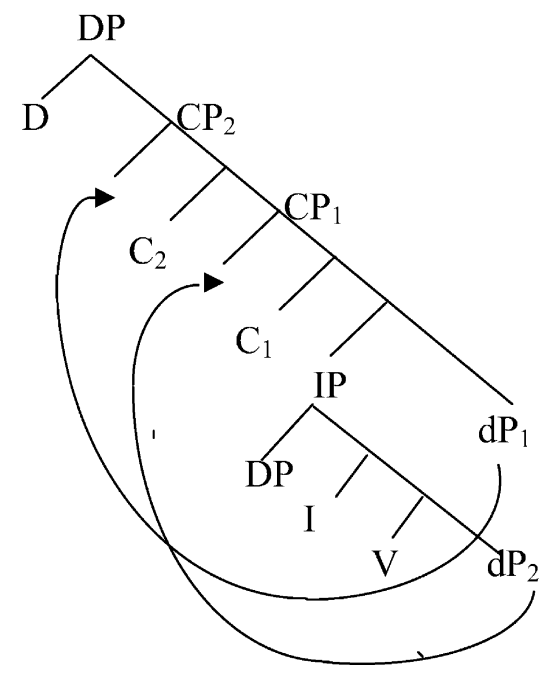

The structure in (29) has the potential to account for the absence of reconstruction effects in matching relatives (see (20)-(23) above) since the two Heads are not part of the same movement chain. In particular, the "overt" Head which is the external Head $\left(\mathrm{dP}_{1}\right)$, is not related to the relative clause internal position by movement. (I will come back to Condition $\mathrm{C}$ effects in section 4.4.) However, movement of the internal Head $\mathrm{dP}_{2}$, being internal to the $\mathrm{RC}$, would predict locality effects to be present in a matching type of structure, which is not always the case, as mentioned. The sharp contrast between relatives containing a gap and resumptive relatives in terms of island sensitivity in Bulgarian (see (30a) vs. (30b)) suggests that movement of the internal Head takes place in the derivation of the former although not of the latter: ${ }^{27}$

(30) a. *Tova e edin film, deto vsicki, koito sa $\mathrm{t}$ gledali, mnogo go xaresvat. this is a film that all which-pl are-3pl seen-prt-pl a-lot it-ClAcc like-3pl 'This is a film that everybody who has seen it likes it a lot'

b. Tova e edin film, deto vsicki, koito sa go gledali, mnogo go xaresvat. this is a film that all which-pl are-3pl it-ClAcc seen-prt-pl a-lot it-ClAcc like-3pl

'This is a film that everybody who has seen it like it a lot'

The internal Head cannot occur within an island if it is a trace of movement, but it can if it is a resumptive clitic:

(31) a. *External Head Internal Head [Island $<$ copy Internal Head $>$ ] $<$ copy External Head $>$

b. External Head [Island CL Internal Head ] < copy External Head $>$

\footnotetext{
${ }^{26}$ Movement of the external Head takes place for reasons to be better understood. Cinque (in preparation) referring to Kayne (2004:205) supposes that in languages with initial complementizers this movement is due to the specific properties of the complementizer itself which attracts the external Head to its specifier. The situation is more complex in languages with final complementizers where the external Head does not always move.

${ }^{27}$ Boeckx (2003:108ff) relates the presence/absence of island effects in resumptive relatives to the type of C: agreeing vs. matching. Within this proposal, deto should be classified as a matching $\mathrm{C}$, given the island insensitivity of the resumptive clitic, i.e. a type of $\mathrm{C}$ that does not enter into an agreement relation with the resumptive clitic, thus allowing the latter to appear inside islands (domains impervious to agreement). Resumption then would involve Move under Match rather than Agree, a stipulation apparently needed only to solve the island-sensitivity problem.
} 
The structure sketched in (31b) produces a grammatical output because the clitic is a "true" resumptive in the sense of Aoun et al. (2001), as discussed in 3.2. above.

To summarize the proposal so far, movement of either the internal or the external Head can derive successfully the two types of Bulgarian RCs involving a complementizer. The two types proposed (raising and matching) have been argued to be both available for the derivation of deto-relatives in the sense that each is "specialized" with respect to semantic considerations that require or do not allow reconstruction. The raising derivation is restricted to relative clauses involving idiomatic readings, amount readings, anaphor and pronominal binding possibilities, and narrow scope interpretation. The matching derivation, on the other hand, is to be applied in the rest of the cases, and may involve an additional relative clause internal movement, which distinguishes the structure containing a gap from the one containing a resumptive element. I will come back to the derivation of resumptive relatives in section 4.5.

\subsection{On the relative order between external and internal Head in gap relatives}

A natural question to ask at this point is: What is the position targeted by the internal Head in gap relatives? Note that from the point of view of the system adopted here, this position must in any case be lower than the position targeted by the external Head, so that the latter can c-command the former and control for its deletion at PF. Corroboratory evidence for the surface relative order between the external Head and the internal Head comes from the distribution of Topic and Focus phrases in deto-relatives. In this subsection I will show that when a Topic or a Focus is present, such a phrase can distinguish clearly between the various positions in the Split CP of the relative clause.

Matching relatives exhibit a clear contrast to raising relatives with respect to the possibility of dislocating a Topic or a Focus phrase within the CP field. (32) contains two instances of a matching derivation: in the first, (32a), a dislocated Topic or Focus phrase is placed to the left of the complementizer, ${ }^{28}$ thus separating it from the relativized Head; in the second example, (32b), taken from a corpus of colloquial speech (Dacheva and Tisheva, 2005), there are two dislocated Topics (as can be inferred by the presence of the resumptive Accusative clitic gi 'them' reduplicating the lower Topic) and both of them intervene between the overt Head and the complementizer ${ }^{29}$ :
a. Tova e ženata, [Top/Foc naj-složnite pesni] deto peeše... ${ }^{30}$ this is woman-the most complex-the songs that sang-3sg 'This is the woman that sang the most complex songs'
b. onja be, [Top za mutrite [Top naj-jakite knigi [deto gi napisa ]]] that-one PRT about criminals-the most-interesting-the books that them-ClAcc wrote-3sg 'that guy that wrote the most interesting books about the criminals'

Given that in a matching derivation the overt relative Head is the external Head, the above examples indicate that the latter raises to a position higher than the Topic and Focus position(s) in the left periphery. Now consider the position that the internal Head raises to. The evidence presented below illustrates that in a raising relative like the idiom chunk in (33a), it is impossible to topicalize or focalize material from within the RC to a position in between the overt Head and the complementizer. Since in a raising relative the overt Head is the internal Head, the ungrammaticality of (33b) can be taken as evidence that there is no "space" between deto and the internal Head to host a designated TopP or FocP, thus confirming our previous suggestion (see the structure in (28b) above) that the internal Head occupies the specifier position of deto. Moreover, (33c) shows that the TopP/FocP can find itself to the left of the internal Head, although it remains to be seen what its exact position is in the case of the raising derivation:

\footnotetext{
${ }^{28}$ For arguments that bear on focus movement to FocP in Bulgarian, I refer the readers to Izvorski (1995), Krapova (2002), and Arnaudova (2003).

${ }^{29}$ Note that in (32b) the two preposed phrases do not form a constituent, since they appear as separate phrases in other contexts not illustrated here.

${ }^{30}$ The preposed constituent can receive a Topic or a Focus reading. Rudin uses this example to argue that deto is not in a Topic position. The same is true of restrictive relative clauses employing a wh-pronoun. Cf. (i) again from Rudin (1986:127, ex. (9a)):

(i) Tova e ženata, [Top/Foc naj-složnite pesni] kojato peeše.

this is woman-the most complex-the songs who-fem sang-3sg

'This is the woman who sang the most complex songs'
} 
(33)
a... Natiskăt, deto Evropa okazva na Bălgarija [zaradi zdravnata reforma],
e neprestanen.

pressure-the that Europe exert-3sg on Bulgaria because-of health-care-the reform is constant

'The pressure that Europe puts on Bulgaria because of the health care reform is constant'

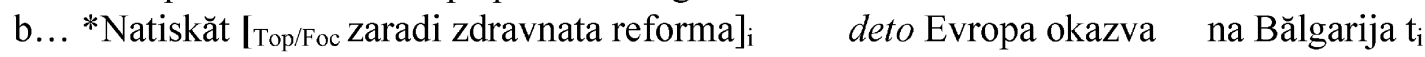

pressure-the because-of health-care-the reform that Europe exert-3sg on Bulgaria

e neprestanen.

is constant

lit. 'The pressure, due to the health care reform, that Europe puts on Bulgaria is constant'

c. ?[Top/Foc Zaradi zdravnata reforma $]_{i}$ natiskăt deto Evropa okazva na Bălgarija $t_{i}$

because-of health-care-the reform pressure-the that Europe exert-3sg on Bulgaria

e neprestanen.

is constant

lit. 'Due to the health care reform, the pressure that Europe puts on Bulgaria is constant'

Taken together, the examples in (32) and (33) show that the external Head raises to a position higher than the Topic and Focus position(s) which in turn, as evident from $(33 b, c)$ above, must be higher than the position to which the internal Head raises. We thus get the following hierarchical order of the CP elements in deto-relative clauses:

$$
\text { external Head }>\text { Topic }>\text { Focus }>\text { internal Head }>\text { deto } \ldots .
$$

If (34) is correct, the complementizer must be occupying a low position in the Split CP hierarchy of the RC's left periphery. ${ }^{31}$ Just the opposite has been argued by Bianchi (1999) for relative that in English on the basis of the embedded topicalization and negative preposing data in $(35 \mathrm{a}, \mathrm{b})$. Given that the complementizer is necessarily found to the left of discourse-related material, Bianchi suggests that that occupies the highest CP position (both in relative clauses and in complement clauses which exhibit similar evidence with respect to the positioning of Topic and Focus phrases, cf. e.g. (35c)). Within the universal structural CP hierarchy proposed by Rizzi (1997) and given in (36), this position is identified as Force. ${ }^{32}$

(35) a. This is the kind of car that [Top for my son] I wouldn't even have considered buying.

(Bianchi 1999:177, ex. (46a))

b. ?I saw a dress that [Foc under no circumstances] would I have considered buying for my daughter.

(Bianchi 1999:177, ex. (47a))

c. He said [that [Top beans $\mathrm{i}_{i}\left[\left[\mathrm{Foc}\right.\right.$ never in his life] [had [he $\mathrm{t}_{\mathrm{AUX}}$ been able to stand $\left.\left.\left.\left.\left.\mathrm{t}_{\mathrm{i}} \mathrm{t}_{\mathrm{ADV}}\right]\right]\right]\right]\right]$

$$
\begin{aligned}
& \text { [Forcep Force [Topp Top [FocP Foc [Topp Top* [FinP Fin IP ]]]]] } \\
& \text { that }
\end{aligned}
$$

(Bianchi 1999:179, ex. (50))

The exact identification of the $C$ head spelled out by deto $\left(C_{1}\right.$ in $(28 b)$ and (29)) remains to be established, but it can be speculated that this position corresponds to Fin (Finiteness), given (34). According to Rizzi (1997), Fin and Force are functionally equivalent in terms of features and can alternate in the sense that either one or the other can be realized overtly, unless splitting is forced by intervening Topic and Focus projections in which case both

\footnotetext{
${ }^{31}$ As pointed out to me by Adam Szczegielniak (p.c.), a pattern similar to that in (i) of footnote 30 is also found in Russian wh-relatives, although not in čto 'that' relatives where a Topic or a Focus phrase is precluded from appearing above the complementizer, a fact which Szczegielniak (2005) interprets as indicating that it occupies a higher position that the $w h$-pronoun. Although no account of $w h$-relatives is intended in this study, plausibly the wh-pronoun in Bulgarian, at least at some point of the derivation, occupies the specifier of the same projection filled by deto in complementizer relatives.

${ }^{32}$ Aoun and $\mathrm{Li}$ (2003:122ff) also assume, following Bianchi (1999), that the position of that is the highest C, namely Force. The two step Head raising derivation they propose for English that relatives is represented in (i) and involves movement of the DP (with a null D) from IP internal position to Spec of a Topic projection followed by subsequent movement of this DP to Spec, ForceP.

(i) $\left[_{D P}[D\right.$ the] [ForceP $[D P$

However, it is not clear under this account how these two CP positions will accommodate an embedded topic such as the one in (35a), given that Spec,TopP is already occupied by the trace of the moved DP, unless a recursive Topic projection is invoked.
} 
must be realized. If Fin is indeed filled by deto, Force can plausibly be taken to correspond to the higher position $\mathrm{C}_{2}$ in (29).

We are now in a position to derive the matching analysis of deto-relatives. Such an analysis can be said to involve the derivation sketched in (37b) for the relative clause in (37a). On the first step, the internal Head is attracted to the specifier of $\mathrm{C}_{1} /$ Fin, given that it cannot be separated from the complementizer deto by intervening (Topic or Focus) material. On the next step, the external Head is attracted to the specifier of Force. On the third step, PF deletion takes place, i.e. the external Head deletes the internal Head and gets pronounced as the overt relative clause Head. $^{33}$

a. ... knigite, deto Ivan kupi 'the books that Ivan bought'

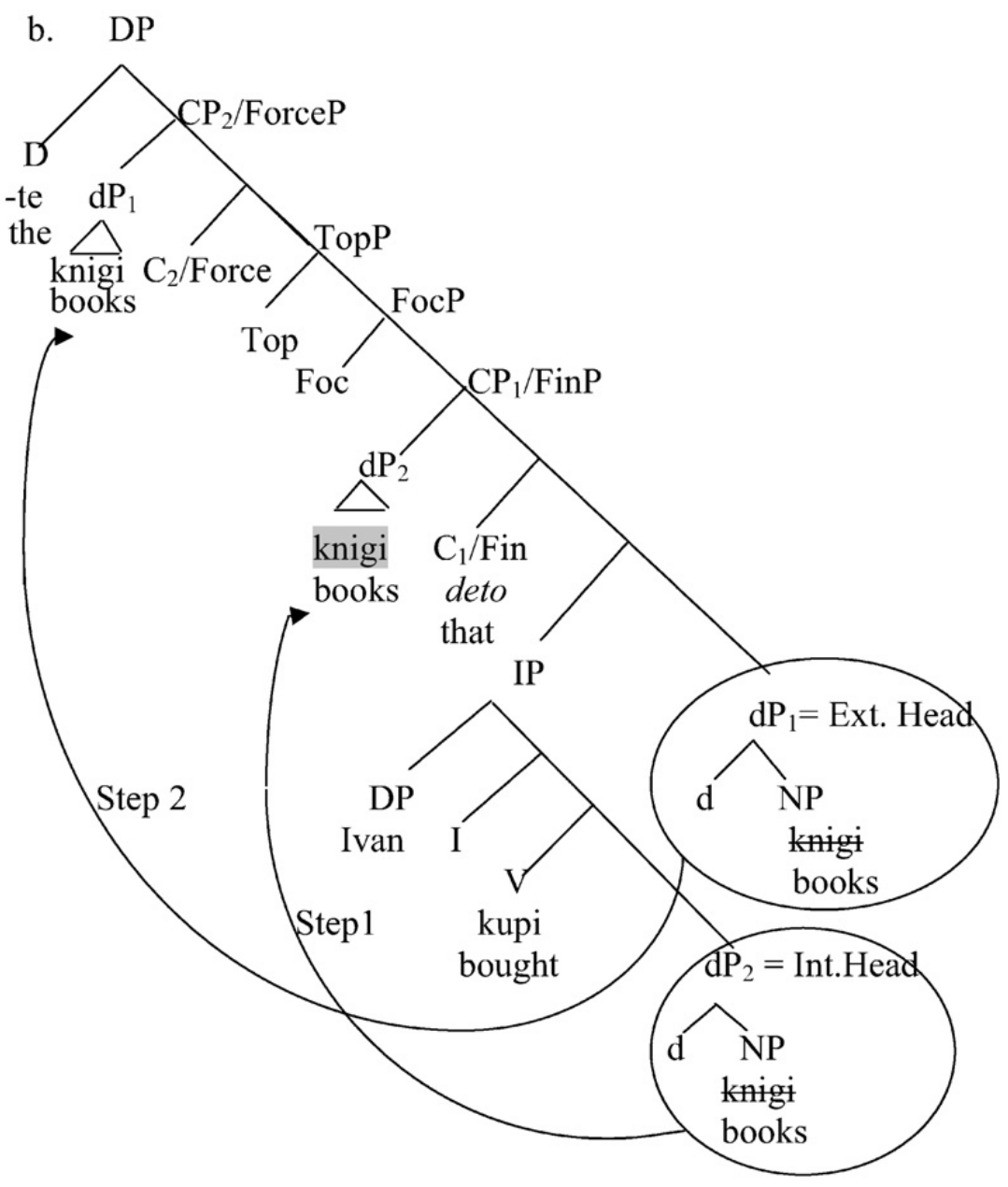

\footnotetext{
${ }^{33}$ Actually, Fin is not the only position available to host deto. As the examples (i)-(iii) show, this complementizer can also (somewhat marginally) appear to the left of Topic and Focus: in (i) it precedes the clitic left dislocated phrase, in (ii) the topicalized phrase, and in (iii) the Focus phrase. To account for these alternative orders, we can assume that in the matching derivation deto has the option of raising above the Topic and Focus positions, landing presumably in Force. What motivates complementizer raising in these cases remains to be understood, however:

(i) ? Rokljata deto $[$ TopP $\mathrm{S}$ velurenite obuvki] ja nosex, veče mi e otesnjala. dress-the that with suede-the shows her-ClAcc wore-1sg already me-ClDat is tight-fem 'That dress I used to wear with the suede shoes is already too tight on me'

(ii) ? Doktorăt deto [Topp Za bolnite] už mnogo se grižeše, go doctor-the that for sick-Pl-the apparently a lot refl took-care-3sg him-ClAcc caught-3pl with bribe 'The doctor that seemed to be taking good care of the patients was caught with a bribe'

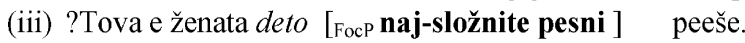
this is woman-the that most complex-the songs sang-3sg 'This is the woman that was singing the most complex songs'
} 


\subsection{An aside on the order of phrasal movements}

The structure in (37b) makes it clear that the surface order of the two Heads reflects their order prior to movement, since the external Head is structurally closer than the internal Head to the CP field in terms of dominating nodes. The principle that ensures the preservation of the order of Merge cannot be Attract Closest (Chomsky, 1995; Bošković, 1997, 1999, 2002; Pesetsky, 2000) since (barring the "tucking-in" mechanism of Richards, 1997, 2001) it would predict that the closer phrase, i.e. the external Head, will move first and end up in the lower CP position, while the more distant phrase, i.e. the internal Head, will move second and end up in the higher CP position. The two movements would thus result in a reversal of the order in (34) above which we have independently established as the correct order between the two Heads.

This situation is reminiscent of the one found with multiple wh-questions in Bulgarian (Rudin, 1988, see (38)), where the fronted $w h$-phrases are ordered according to Superiority: the wh-phrase that is merged closer to CP (the subject koj 'who') ends up higher than the one that is merged lower (the object kakvo 'what'). Movement thus results in a preservation of the initial order between the wh-phrases (cf. also Bošković, 1997, 1999). For a more extensive discussion of Superiority effects in multiple $w h$ fronting in Bulgarian the reader is referred to Bošković (1997, 1999, 2002), Richards (1997, 2001), Pesetsky (2000) and Krapova and Cinque (2008a):

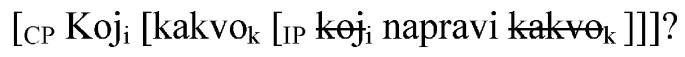

$$
\begin{aligned}
& \text { who what did-3sg } \\
& \text { 'Who did what? }
\end{aligned}
$$

While there have been a number of proposals to capture this (selective) Superiority effect, in Krapova and Cinque (2008a) we argued that it can be derived from Relativized Minimality if one adopts and extends to A-bar chains a principle originally proposed in Chomsky (2000, section 6; 2001, (17)) for A-chains. See (39):

(39) Only a whole (A or A-bar) chain, not just a link of a chain, counts as an 'intervener' for Relativized Minimality.

Relativized Minimality can be formulated as in Rizzi (2001) as a condition on chain links, (40), itself based on the Minimality notion given in (41) below:

(40) $\left(A_{1}, \ldots, A_{n}\right)$ is a chain iff, for $1 \leq \mathrm{i}<\mathrm{n}$

(i) $A_{i}=A_{i+1}$

(ii) $\mathrm{A}_{\mathrm{i}} \mathrm{c}$-commands $\mathrm{A}_{\mathrm{i}+1}$

(iii) $A_{i+1}$ is in a Minimal Configuration with $A_{i}$

(41) $\mathrm{Y}$ is in a Minimal Configuration with $\mathrm{X}$ iff

there is no $\mathrm{Z}$ such that

(i) $\mathrm{Z}$ is of the same structural type as $\mathrm{X}$, and

(ii) $\mathrm{Z}$ intervenes between $\mathrm{X}$ and $\mathrm{Y}$

In other words "each chain link involves identity (under the copy theory of traces), c-command and Minimality" (Rizzi, 2001:91). In the spirit of Rizzi (2001), Krapova and Cinque (2008a) take Z to count as an intervener between a trace $\mathrm{Y}$ and a target $\mathrm{X}$ if $\mathrm{Z} \mathrm{c}$-commands $\mathrm{Y}$ without $\mathrm{c}$-commanding $\mathrm{X}$, and if it is specified with the same feature as the target (quantificational, modifier (non-quantificational), etc.).

Within a system in which Superiority is subsumed under Relativized Minimality, the preservation of the premovement order of the phrases in the case of multiple movements can be ensured through the requirement in (39), which is a modification, as noted, of one of Chomsky's principles. ${ }^{34}$ In other words, no (trivial or non-trivial) chain can intervene between the lower and the higher copy of another chain, if the two chains contain non-distinct features.

With (39), the order of the two exact copies of the relative clause Head in (37b), i.e. the external Head and the internal Head, can now be seen to follow from Relativized Minimality. The relevant derivations, and the resulting

\footnotetext{
${ }^{34}$ Chomsky's condition reads "Only the head of an A-chain (equivalently, the whole chain) blocks matching under the Minimal Link Condition" (Chomsky, 2001, (17)). Rizzi reached a conclusion similar to that of Chomksy's in unpublished work refining his (1990, 2001) notion of Relativized Minimality.
} 
representations are given in $(42 a, b)$. (42a) represents the only possible order of the two movements which respects both Relativized Minimality and the Extension Condition. (42b), on the other hand, violates Relativized Minimality whatever the order of the two movements is (and the Extension Condition in one of the two possible derivations). ${ }^{35}$

(42)

a.

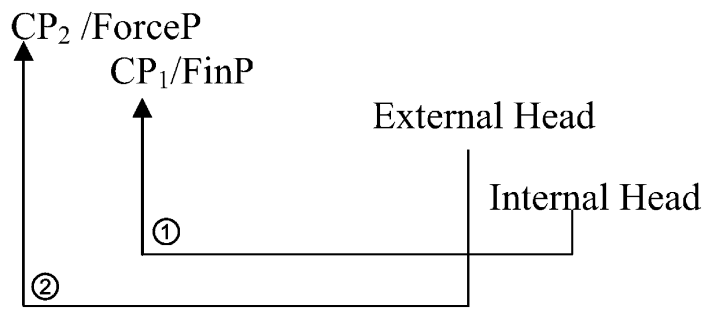

b. $\quad * \mathrm{CP}_{2} /$ ForceP

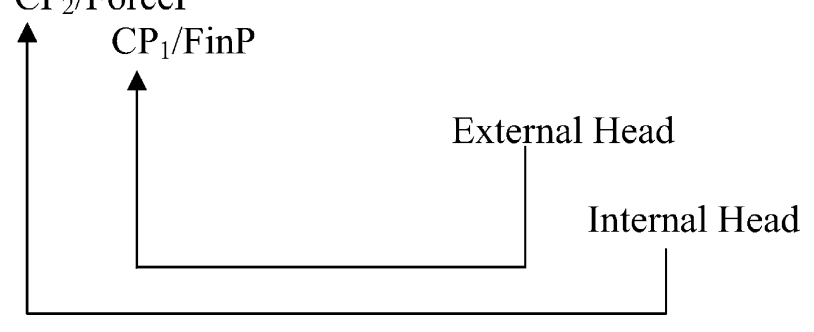

In (42a) there is only a link of a chain (not an entire chain) intervening between the lower copy of the internal Head inside the RC (the 'tail' of the chain) and the higher copy in Spec, $\mathrm{CP}_{1}$ (the 'head' of the chain). Similarly, only a link of a chain intervenes between the 'head' and the 'tail' of the chain created by movement of the external Head. Not so in (42b) where the entire (non-trivial) movement chain of the external Head intervenes between the two copies of the internal Head. ${ }^{36}$

To summarize, in this section I have shown that in matching gap relatives the external Head counts as the "overt" head since it targets the higher $\mathrm{CP}$ position $\left(\mathrm{Spec}, \mathrm{CP}_{2} / \mathrm{ForceP}\right.$ ) and gets pronounced after PF deletion of the internal Head located in the lower CP position (Spec, $\mathrm{CP}_{1} / \mathrm{FinP}$ ). The order of the two movements preserves the order of the two Heads at Merge in a manner respectful of Relativized Minimality and the Extension Condition.

\subsection{Principle $C$ effects}

Principle C effects deserve special attention since strictly speaking, under representation (37b) and a copy theory of movement, a Principle $\mathrm{C}$ violation should be expected, contrary to fact. For example in (23) above repeated below as (43a), the R-expression (Ivan) in the internal Head $\mathrm{dP}_{2}$ - see (43b) - should be able to reconstruct to the internal gap position, giving rise to a Principle $\mathrm{C}$ violation. As the sentence is grammatical, something special needs to be said about why that structure is allowed to void a Principle $\mathrm{C}$ violation:

(43) a. Onazi snimka na $\operatorname{Ivan}_{\mathrm{i}}$, deto toj $\mathrm{j}_{\mathrm{i}}$ xaresva mnogo, e naistina xubava. that picture of Ivan that he like-3sg a lot is really nice

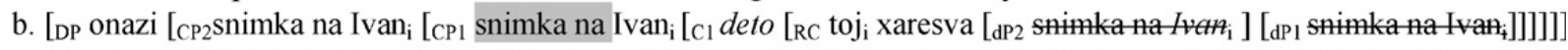
that picture of Ivan picture of Ivan that he likes picture of Ivan picture of Ivan

In the resolution of ellipsis, a number of non-equivalencies between overt antecedents and their elliptical counterparts have been observed, most prominently by Fiengo and May (1994), who name this phenomenon vehicle change. Vehicle change was originally proposed on the basis of certain VP deletion facts in English, more specifically the fact that when the R-expression is more deeply embedded in the VP of the second conjunct, as in $(44 \mathrm{~b}, \mathrm{c})$ which contrast

\footnotetext{
35 Note that under this account of Superiority, it is crucial that Relativized Minimality applies at the end of the derivation, or on the representation. See Rizzi (2001, especially fn.6) for arguments to this effect.

36 The conclusion we can draw from the contrast between (42a) and (42b) has the general consequence of forcing a crossing (rather than a nesting) derivation of the Heads.
} 
with (44a), a coreference relation is possible. Fiengo and May contend that in such cases the R-expression in the antecedent can correspond to a pronoun in the VP undergoing ellipsis. Given that the pronominal complies with Principle B in $(44 b, c)$ (though not in $(44 a))$, no violation of this Principle is to be expected there. ${ }^{37}$

(44) a. *John likes Mary ${ }_{i}$ and she $_{i}$ does $<$ like her $>$ > too.

b. John likes Mary ${ }_{i}$ but she $e_{i}$ thinks he doesn't $<$ like her $_{i}>$.

c. John likes the story about Mary ${ }_{i}$ and she $e_{i}$ knows he does $<$ like the story about her ${ }_{i}>$

Following Sauerland $(1999,2003)$ who in turn follows Fiengo and May (1994) (cf. also Safir, 1999), I tentatively suggest that the absence of Principle $\mathrm{C}$ effects in matching deto RCs containing a gap can be explained by way of vehicle change applying before movement takes place. As indicated by the indices in the schematic representation (45), vehicle change transforms the R-expression in the internal Head into a pronoun (nego 'him'), which can then be interpreted as coreferent with the R-expression in the external Head (Ivan). Given that a pronoun counts as non-distinct from the proper name that it stands for (for a discussion of non-distinctness see Chomsky, 1965), the two Heads should also count as non-distinct (in a sense to be made more precise though), with the external Head acting as the antecedent of both (unpronounced) copies of the internal Head - the higher one in $\mathrm{Spec}, \mathrm{CP}_{1} / \mathrm{FinP}$ and the lower one inside the $\mathrm{RC}$ (the reconstructed position). If so, no Principle $\mathrm{C}$ violation is expected under coreference between the lower copy of the internal Head and the subject of the relative clause IP:

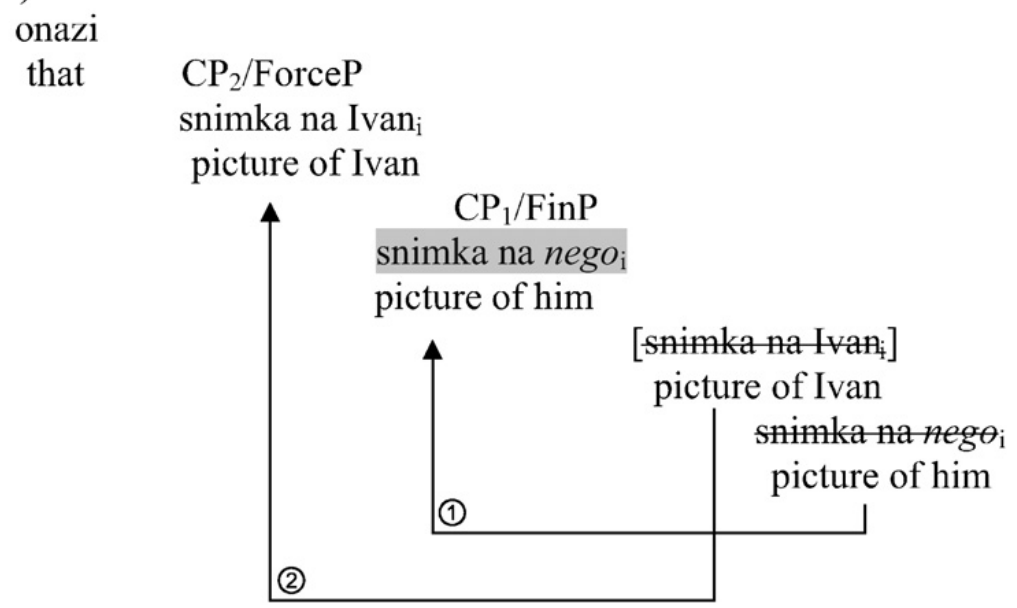

\subsection{The derivation of deto-relatives containing resumptive clitics}

A structural account like the one sketched above in (37b) should in principle be possible for deriving RCs which contain a resumptive clitic. It will be recalled that they are necessarily matching relatives not sensitive to islands. Since movement of the internal Head is unavailable in this case, the first step of the derivation in (37b) does not take place. Instead, an empty operator is merged in $\mathrm{Spec}, \mathrm{CP}_{1} / \mathrm{FinP}$ to establish the desired link with the resumptive pronoun contained in the internal Head through binding. The derivation then proceeds by raising of the external Head to Spec $\mathrm{CP}_{2} / \mathrm{ForceP}$. The clitic on the other hand leaves the complex Internal Head and gets cliticized to the verb, presumably by left-adjoining to it. ${ }^{38}$ At the last stage the internal Head is deleted in situ stranding the resumptive clitic. The relevant structure is given in (46).

\footnotetext{
${ }^{37}$ Vehicle change can be assumed to apply only in case the derivation involves two chains. If this were not the case, we should expect, contrary to fact, absence of a Principle $\mathrm{C}$ effect even when reconstruction takes place in a single chain like the one formed by overt $w h$-movement ((i)), whatever the analysis of $w$-relatives. See also footnote 15 :

(i) *Koja snimka na $\operatorname{Ivan}_{\mathrm{i}}$ toj $_{\mathrm{i}} \mathrm{ja} \quad$ xaresva snimka na Ivan?

which picture of Ivan he her-ClAcc like-3sg

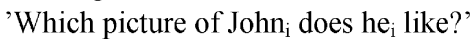

${ }^{38}$ As is well-known, Bulgarian clitics are verb-adjacent and appear immediately preceding the finite verb. Since the exact way in which this is achieved is immaterial to our purposes, I do not discuss the issue here. For an extensive discussion of the various syntax-based accounts of clitics in Bulgarian, see Bošković (2001, chapter 4) and Franks and Rudin (2005) for comments relevant to the mechanism of clitic doubling.
} 
(46)

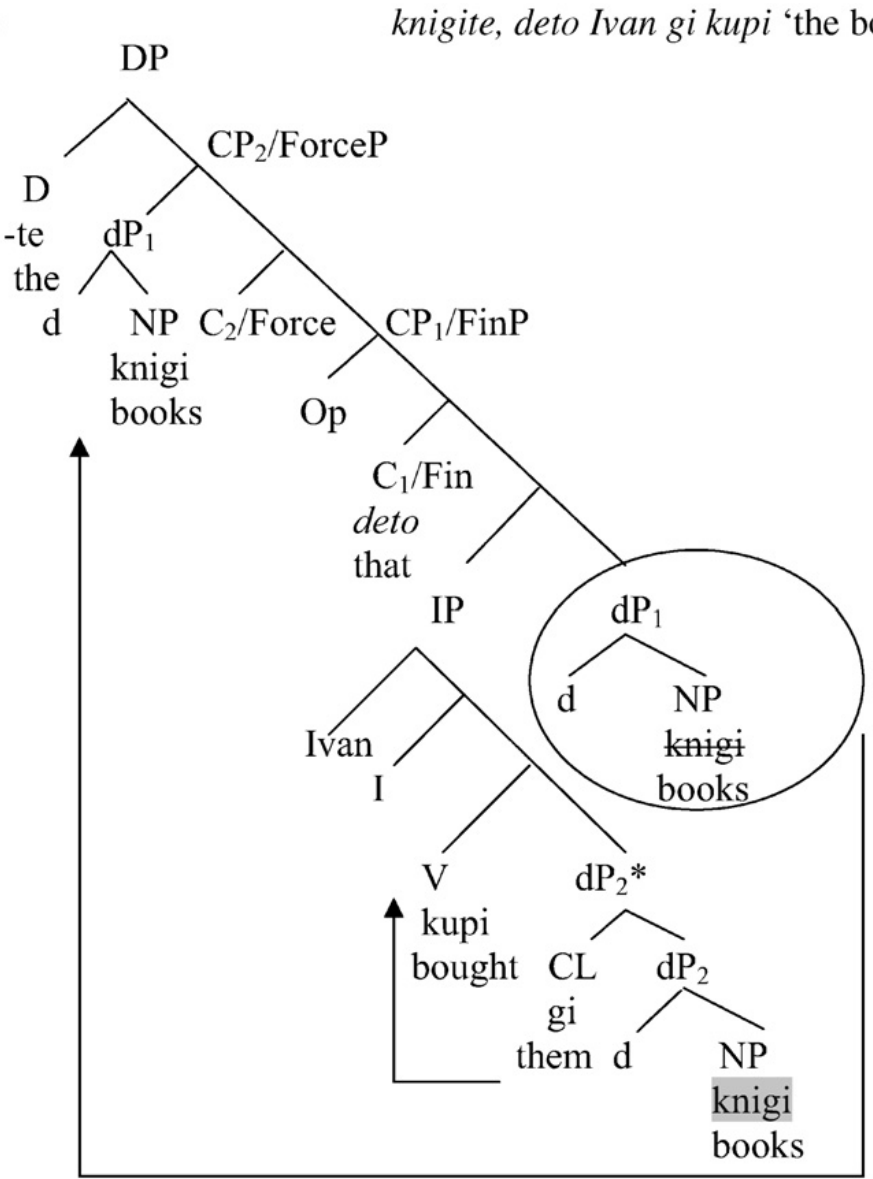

The absence of Principle $\mathrm{C}$ effects in resumptive relatives (see section 3.2 and example (23) repeated below as (47)) can be explained by invoking again the workings of the mechanism of vehicle change. The "offending" R-expression within the internal Head (Ivan) gets replaced by a pronoun (nego 'him') that can enter into a coreference relation with the R-expression contained in the external Head in Spec, $\mathrm{CP}_{2} /$ ForceP which counts as its antecedent. ${ }^{39}$ The resulting structure is represented in (48):

(47) Onazi snimka na $\operatorname{Ivan}_{\mathrm{i}}$, deto toj $\mathrm{j}_{\mathrm{i}} \mathrm{ja}$ xaresva mnogo, e naistina xubava.

that picture of Ivan that he her-ClAcc likes a lot is really nice

lit. 'that picture of Ivan that he likes a lot'

(48)

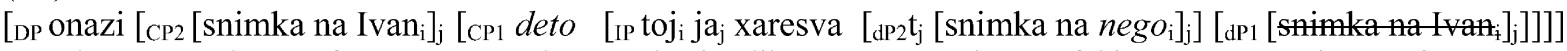

that picture of Ivan that he it likes picture of him of Iran

\section{6. "Apparent" and "true" resumption in Bulgarian}

The presumed structure of the complex internal Head $\mathrm{dP}_{2} *$ in (46) is easily recognized as similar in spirit to a 'BigDP' type of structure recently proposed by Boeckx (2003) for resumptive relatives. According to this approach, the resumptive pronoun/clitic (RP) is merged in the D-layer of its associate antecedent (the relativized NP, see (49)) in a 'clitic doubling' configuration of the type proposed by Kayne (1972), Uriagereka (1995), and Torrego (1998) and

\footnotetext{
${ }^{39}$ Since nego 'him' is within a picture NP, no Principle B violation is to be expected. For reasons of clarity, I have chosen nego 'him' as a pronominal replacement of the R-expression in vehicle change contexts, although in ordinary usage the adjectival possessive (negova 'his') is preferred, whenever possible.
} 
subsequently extended to clitic left dislocation (Cecchetto, 2000). Resumptive chains are essentially derived by independent A-bar movement of the antecedent, leaving the clitic stranded within IP:

$$
\text { [DP D (RP) [NP Antecedent]] }
$$

(Boeckx 2003, 154, (105))

One drawback of this structure, as pointed out by Bianchi (2008), comes from the fact that the parallelism with clitic doubling/clitic left dislocation which Boeckx tries to capture breaks down when considering the nature of the moved element: in both clitic doubling and clitic left dislocation what is moved is typically a full DP rather than a proper subconstituent of it. See also the examples in (51) below from Bulgarian.

Franks and Rudin (2005) propose, also in the spirit of Uriagereka (1995), an account of obligatory resumption in clitic doubling/Topic (clitic left dislocation) structures in Bulgarian. ${ }^{40}$ On their view, Bulgarian clitics are agreement elements (rather than true pronouns) and require more structure than just D; more precisely, they are heads of a bigger projection labelled KP (as in the rest of Slavic) and consisting of $\mathrm{K}^{0}$ plus a DP complement, cf. (50). Doubling obtains when the DP moves out through Spec,KP, triggering Spec-head agreement, instantiated by the overt clitic pronoun. Further movement of the associate to the left periphery derives the Topic (clitic left dislocation) structure underlying the examples in (51):

(50) $[$ Kе [K CL [DP D NP/QP/AP]]]

(51) a. Marija/Tazi žena Ivan *(ja) običa.

Maria/ this woman Ivan her-ClAcc love-3sg

'Maria/This woman, Ivan loves her'

b. Edno momče *(go) boli glavata.

one boy him-ClAcc hurt-3sg head-the

'A boy has a headache'

Crucially, Franks and Rudin demonstrate that cases parallel to (51) share all the hallmarks of a movement derivation. Not only is clitic left dislocation allowed in precisely those environments in which $w h$-movement is also allowed (though Cinque, 1990, chapter 2, shows that the counterpart of successive cyclic wh-movement is systematically precluded), but both obey strong island constraints. For example, as illustrated in (52a), the resumptive clitic is sensitive to the Complex NP Constraint, exactly as the gap left by $w h$-movement in (52b). ${ }^{41}$ Additionally the minimal pair in $(52 \mathrm{c}, \mathrm{d})$ shows that while the possessive reflexive clitic si 'her' may be bound by the negative quantifier nikoj 'nobody' following reconstruction of the clitic left dislocated phrase, no such possibility exists if the clitic is within an island.

(52)
a. *Marija ${ }_{i}$ sreštnax [ măža [ kojto ja $a_{i}$ običa]] Marija met-1sg man-the who her-ClAcc love-3sg
b. *Kogo sreštnax [măža [kojto običa _ ]]? whom met-1sg man-the who love-3sg
c. $\left[\text { Starite } \mathrm{si}_{\mathrm{k}} \text { drexi }\right]_{\mathrm{i}} \quad$ nikoj $_{\mathrm{k}}$ njama da $\mathrm{gi}_{\mathrm{i}}$ obleče na praznika.
old-the his-refl ${ }_{k}$ clothes nobody $_{k}$ will-not Mod them-ClAcc wear-3sg at celebration-the
'His old clothes nobody is going to wear [them] at the celebration'
d. *[Starite $\mathrm{si}_{\mathrm{k}}$ drexi] $]_{\mathrm{i}}$ ne poznavam [nikojk, [kojto šte gi $\mathrm{i}_{\mathrm{i}}$ obleče old-the his-refl clothes not know-1 sg nobody who-m will them-ClAcc wear-3sg na praznika]]
at celebration-the
lit. 'His old clothes, I don't know anyone who will wear [them] at the celebration'

\footnotetext{
${ }^{40}$ But see Krapova and Cinque (2008b) for a finer-grained distinction between clitic doubling, (51b), and clitic left dislocation, (51a), in Bulgarian.

${ }^{41}$ The same seems true for $w h$-relatives which arguably also involve movement (cf. Rudin, 1986:136). See the examples in (i):

(i) a.*Vidjax edna kniga, kojato faktăt, če (ja) prodavat, me iznenada.

saw-1sg a book who-fem fact-the that her-ClAcc sell-3pl me-ClAcc surprised-3sg

'I saw a book that that the fact that they're selling it surprised me'

b. *čovekăt, kojto tja se uplaši, $\quad$ kato (go) vidja.

man-the who-m she refl got-scared-3sg when him-ClAcc saw-3sg

'the man who she got scared when she saw him'
} 
Reconstruction therefore is unavailable in a context from which movement is impossible, such as a (strong) island:

(53) a. $\mathrm{DP}_{\text {Topic }} \ldots\left[\ldots \mathrm{CL}<\right.$ copy $\mathrm{DP}_{\text {Topic }}>$ ] - reconstruction available

b. $\mathrm{DP}_{\text {Topic }} \ldots\left[\right.$ [island $\ldots . . \mathrm{CL}<$ copy $\mathrm{DP}_{\text {Topic }}>$ ] - reconstruction unavailable

Given the data in (52) and the generalization in (53), the resumptive clitic in the clitic left dislocated construction corresponds to an "apparent" resumptive element in the sense of Aoun et al. (2001), a behavior correctly captured by the movement approach advocated in Franks and Rudin (2005). ${ }^{42}$ The contrasting properties of the clitic in detorelatives argued above (on the basis of (21) and (25)) to correspond to a "true" (although not last resort) resumptive might at first sight cast doubt on the possibility of extending Franks and Rudin's proposal to relative clauses. Nevertheless I believe that a 'complex DP' type of approach can still be maintained although in a slightly modified form.

As mentioned above (see section 4.1) and indicated in all of the structures given so far, in Cinque's (2008) system, the relative Head (in its two non-distinct copies) is a phrase smaller than DP, what he refers to as dP ('indefinite phrase'). Such a proposal, based on independently established evidence that Numerals/Indefinite Determiners, Adjectives, and the NP are the elements that may occur below the RC merged prenominally, implies that non-specific phrases can also be relativized. The following examples show that resumptive deto-relatives need not have a specific interpretation but can have an indefinite or a generic Head: ${ }^{43}$

(54) a. Ne običam knigi, deto vseki *(gi) čete samo zaštoto sa modni. not like-1sg books that everybody them-ClAcc read-3sg only because are-3pl fashionable-pl 'I don't like books that everybody reads only because they are fashionable'

b. Njama film, deto da ne săm go gledal. has-not film that Mod not am it-ClAcc seen-prt-sg

'There is no film that I haven't seen'

'Doubling' is impossible in the corresponding Clitic left dislocated construction, as has been noted by numerous researchers following Ivančev (1978):
a. *Knigi vseki gi čete zaštoto sa modni books everybody them-ClAcc reads because are fashionable
b. *Nikoj film ne săm go gledal.
no film not have-1sg it-ClAcc seen-prt-sg

Even when the noun is drawn from the numeration with the definite article suffixed onto it, as mentioned in footnote 23 , the presence of the definiteness marker does not imply that the clitic's phrasal associate must be a full DP at Merge. One can plausibly assume that the definiteness/specificity feature is checked only after raising of the respective nominal projection to Spec,DP. So, we can conjecture that in (46), the clitic's associate is a dP with a null d, corresponding to the null indefinite marker (see Izvorski, 1993), which is underspecified for specificity. ${ }^{44}$ However, this structure is never instantiated overtly, since movement of the internal Head $\left(\mathrm{dP}_{2}\right)$ is not forced in a matching structure involving a resumptive clitic, as already discussed in relation to the absence of island effects, and the clitic's associate deletes at PF in situ (or in Spec,dP as in Franks and Rudin's (2005) approach). In CD/Topic constructions, on the other hand, the clitic's associate is syntactically active and moving out of the 'complex DP', produces the effects in (51) and (52). These two options may be taken to correspond to the two different ways in which the empty category associated with the clitic is formed in an obligatory 'clitic doubling' configuration at Merge (a-là Kayne, 2002):

\footnotetext{
42 As discussed in Boeckx (2003:157ff), in a number of languages (Yiddish, Welsh, Standard Arabic) resumptive pronouns under wh-movement differ from the ones found under relative clause formation in terms of island sensitivity.

${ }^{43}$ Additionally, the examples show that there is no obligatory matching in definiteness between the overt Head and the complementizer (as has been claimed for corresponding $p u$ 'that' relatives in Greek, Alexopoulou, 2006:22).

${ }^{44}$ The featural specification of $d$ remains to be established in future work. In any case, such a solution avoids the undesirable consequence of the DP analysis proposed in Boeckx (2003), which, as observed by Bianchi (2008), implies that relative clauses with a specific interpretation of the "head" should always have a resumptive pronoun (given that the D-layer encodes specificity), which however is not the case neither crosslinguistically, nor in Bulgarian.
} 
'trace'/copy of movement vs. an in situ deleted phrase. Thus, the "neat opposition" between movement-derived ("apparent") resumption and non-movement-derived ("true") resumption can be maintained.

\section{Deto in factive clauses}

This section will present, in a somewhat descriptive way, the second type of contexts where deto may appear, namely as an apparent subordinating conjunction after emotive predicates, more precisely predicates of emotive reaction or emotive appraisal. ${ }^{45}$ The class includes several verbal and adjectival predicates such as săžaljavam 'regret', vinoven săm 'be one's fault', jad me e 'be sorry; regret', radvam se 'be happy', nedovolstvam 'be dissatisfied', pritesnjavam se 'worry', žal mi e 'be sorry', măčno mi e 'be sad', sram me e 'feel ashamed'. Some examples are given in (56) taken from oral and written colloquial speech:

(56) a. Naistina săžaljavam, deto/če ne otdelix poveče vnimanie na postrojkata. really regret-1sg that not devoted-1sg more attention to construction-the 'I really regret that I did not devote greater attention to the construction'
b. Samo me
e jad, deto/če grivnata izčezna sled zatămnenieto. only me-ClAcc is anger that bracelet-the disappeared-3sg after eclipse-the 'I am only angry that the bracelet disappeared after the eclipse.'

In this section, I am going to argue that although with these predicates deto seems to freely alternate with the default indicative complementizer $\check{c} e$ 'that' (apart from distinctions of style and/or register), it should not be characterized as propositional, but as a relative complementizer. In other words, my proposal is that $(56 \mathrm{a}, \mathrm{b})$ contain a hidden relative structure underlying the apparent complement clause introduced by deto.

Before I turn to arguments supporting this conclusion, I will briefly mention some generalizations concerning the distribution of deto in such contexts. The first generalization is that the predicates that may select for this complementizer are not just emotive, but also factive, i.e. the truth of their complements is presupposed (Kiparsky and Kiparsky, 1971). This can be seen from the three examples in (57) containing the factive verb săžaljavam 'regret': (57a) presupposes that the meeting has failed, although the speaker does not regret that; (57b) presupposes that the visitors arrived late although the speaker believes this is not his fault. Additionally, (57c) shows that adding an extra clause which cancels the presupposition of the factive complement results in a contradiction:
a. Nikak ne săžaljavam, deto/če sreštata im se e provalila. not-at-all not regret-1sg that meeting-the their refl is failed-prt 'I do not regret at all that their meeting has not taken place'
b. Vinoven li săm deto/če gostite pristignaxa kăsno? guilty $\mathrm{Q}$ am that the guests arrived-3pl late 'Is it my fault that the guests arrived late?'
c. Săžaljavam, deto/če ne moža da ostaneš poveče (*no vsăšnost ti ostana poveče). regret-1sg that not could-2sg Mod stay-2sg more (but in fact you stayed-2g more) 'I regret that you couldn't stay longer (but in fact, you stayed longer)'

Given that the truth presupposition cannot be cancelled, and remains unaffected by the presence of matrix operators such as negation and the question operator, deto could be said to signal 'factivity'. However, this would not be correct since the above enumerated predicates constitute only a subset of the ones mentioned as factive in Kiparsky and Kiparsky (1971). For no obvious reason transitive verbs such as razbiram 'comprehend', vzemam previd 'take into account', imam predvid 'bear in mind', prenebregvam 'ignore', văzmuštavam se 'resent', griža se 'take care' cannot take a deto-complement. Semi-factives are excluded too (e.g. znaja 'know', pomnja 'remember', otkrivam 'find out',

\footnotetext{
$\overline{45}$ The phenomenon shows up with great frequency in colloquial speech, but it is also recurrent in literary texts where it has a certain stylistic import. Traditional grammars refer to this usage of deto (appearing also in the form zadeto) as a "mixed object and causal complement" (AG, 1983:378). Cf. also the text below.
} 
viždam 'see', čuvam 'hear', zabeljazvam 'notice'). The examples in (58) are thus possible with a če complement only. ${ }^{46}$ The precise generalization seems to be that the distribution of deto complements is limited to a subset of 'true' factives, including emotives: ${ }^{47}$

(58) a. Văzmutix se če/*deto ne sa mogli da provedat sreštata. resent-1sg refl that not are-3pl able-pl Mod organize-3pl meeting-the 'I resent [the fact] that they were not able to organize the meeting'

b. Otkrix $\check{c}$ e/ ${ }^{*}$ deto sreštata im se e provalila. found-out-1sg that meeting-the their refl is failed-prt 'I found out that their meeting has failed'

The next generalization concerns selection. There is one common property shared by all predicates compatible with a deto-complement, namely they also select for a PP complement headed by the preposition $z a$ 'for'. This can be illustrated by $(59 a, b)$ which give the nominal paraphrases of (57a) and (57b), respectively. Other prepositions or preposition-less DPs are excluded:

(59) a. Săžaljavam za/*na/* $\varnothing$ provala na sreštata. regret-1sg for/of failure-the of meeting-the 'I am sorry about the failure of the meeting'

b. Vinoven li săm za $/ *$ na $/ * \varnothing$ zakăsnenieto na gostite? guilty $Q$ am for/of delay-the of visitors-the 'Am I responsible for the late arrival of the guests?'

Given this additional restriction, it becomes evident why a deto-complement is allowed only with a subset of emotive factives, namely those that subcategorize for the preposition $z a$ 'for'. That the two conditions must be simultaneously present can be seen by the ungrammaticality of deto in cases such as (58a) above: văzmuštavam se 'resent' satisfies the

\footnotetext{
${ }^{46}$ The complementizer $\check{c} e$ 'that', as mentioned, is the default complementizer in Bulgarian, so it may show up in all complement clauses, irrespectively of whether factivity is triggered or not. This fact, as well as the discussion to follow about the status of deto, might be taken to suggest that factivity in Bulgarian is not related to the choice of a particular complementizer, but to the factive context per se. For example, in (58a) the $\check{c} e$ complement also receives a factive interpretation, as can be established by the usual tests for factivity, cf. (i):

(i) Văzmutix se če ne sa mogli da provedat sreštata. (*no vsăšnost te provedoxa sreštata)

resent-1sg refl that not are-3pl able-pl Mod organize-3pl meeting-the (but in-fact they organized-3pl meeting-the)

'I resent [the fact] that they were not able to organize the meeting' (*but in fact they did organize the meeting).

${ }^{47}$ Macedonian and Serbo-Croatian possess a complementizer (što 'that') which exhibits similar selectional restrictions in that it can be used to introduce complements of emotive factive predicates. In both languages this complementizer derives from the interrogative pronoun meaning what (rather than from a relative adverbial as in Bulgarian) and functions as an (invariant) relativizer as well. In standard Macedonian, as in colloquial Bulgarian, it can alternate in factive clauses with the default declarative complementizer deka 'that', which, similarly to deto, derives from the locative adverbial $k a ̆ d e$ 'where' cf. (i). In Serbo-Croatian however što and the declarative complementizer ( $d a$ 'that') seem to be in (near) complementary distribution. Što clauses entail a truth presupposition and have been analyzed by Browne (1986) as specialized for factivity, cf. (ii); $d a$ clauses on the other hand entail no truth presupposition, cf. (iii), and are almost never used with (true) factive verbs. Example (i) is from Tomić (2006) and (ii)-(iii) from Browne (1986):
}

(i) Se raduvam, što /deka ve gledam refl. rejoice-1sg that you-ClAcc see-1sg

(Macedonian, Tomić 2006: 419)

'I am glad to see you'

(ii) Radujemo se što su stigli we-be-glad refl that are-3pl came

'We are glad that they came'

(iii) Verujem da je Jovan bolestan. believe-1sg that is John sick

'I believe that John is sick' (But he might not be.)

It seems therefore that we might be dealing with a similar pattern of complementation in Balkan Slavic. This (tentative) conclusion might have diachronic implications, in the sense that on its way to becoming a general complementizer, the invariant relativizer first extends to factive structures and only afterwards to other structural domains. This can be informally represented in the following partial implicational hierarchy the correctness of which requires further research:

(iv) Relative clauses $>$ emotive factive clauses $>$ all factive clauses 
semantic criterion, but it does not take a $z a$-PP complement, which is why a deto-complement is disallowed with this kind of predicate. ${ }^{48}$

The same syntactic restriction may be at the basis of Rudin's (1986:45ff) observation that, unlike če, deto cannot introduce a sentential subject which is also factive. See the contrast in (60):
a. $\check{C}$ e toj e xubav, ne me iznenada.
(Rudin 1986:45, ex. (6a))
that he is handsome, not me-ClAcc surprised-3sg
'That he is handsome did not surprise me'
b. ${ }^{*}$ Deto toj e xubav, ne me iznenada.
that he is handsome, not me-ClAcc surprised-3sg

Although an account of factivity in Bulgarian remains outside of the scope of this work, I would like to suggest, following standard treatments of factive clauses, which, after Kiparsky and Kiparsky's (1971) analysis, posit a nominal projection (a D head) above CP, that deto complements too contain an (expletive) D head realized by the demonstrative pronoun tova 'this' referring to the content of the proposition contained in the deto-clause. However, given the subcategorization requirements of the predicates which may select for a deto-clause, I further propose that the 'factive' DP structure is actually embedded in a PP headed by the preposition $z a$ 'for', as illustrated in (61). Both the demonstrative and the preposition can be null (or deleted), giving the impression that we are dealing with a complement clause:

(61) Săžaljavam/Jad me e/ Măcno mi e ... [pp [p za/ $\varnothing[$ DP $\mathrm{D}$ tova/ $\varnothing \quad[\mathrm{cP}$ deto $\ldots . . . .]]]$. I regret/ I am sorry/ I am angry for this that

If correct, (61) means that factive deto is a relative clause in disguise and thus a subcase of the headed relatives we have seen so far. The only structural difference between the two lies in the additional PP structure required by the factive deto RC. ${ }^{49}$

Support for this analysis comes from the possibility of merging the preposition with the complementizer, forming a complex (prepositional) complementizer zadeto 'for that' which is sometimes (depending on verb semantics) used to introduce complements to the same factive predicates compatible with $\operatorname{deto}^{50}$ :

\footnotetext{
${ }^{48}$ Thanks to an anonymous reviewer for bringing this point to my attention. Moreover, deto is impossible with verbs that take a $z a$-PP complement but are not factive.

${ }^{49}$ An anonymous reviewer points out that this raises the question of whether Bulgarian uses deto in restrictive relative clauses precisely because of their factivity. This would indeed be desirable given that restrictive relatives have been argued at least since Lakoff (1972) to be presupposed, a feature usually taken to reside in D. However, it is not the case that deto-relatives are always presupposed and, as discussed in section 4.6, the relative Head need not be definite or generic. Two more examples are given in (i):

(i) a. Njama čovek, deto ne revnuva.

has-not person that not is-jealous

'There is nobody who is not jealous'

b. Njama blagina, deto da ne e fakt blogadarenie na mărzelivite.

has-not benefit that Mod not is fact thanks to lazy-the-pl

'There is no good thing that has not become a fact thanks to the lazy people'

Bulgarian deto-relatives thus differ from Serbo-Croatian što 'that' + resumptive pronoun relatives, which, as noted by Browne (1986:71), are necessarily presupposed and possible with familiar referents only, i.e. known to both the speaker and hearer, a property which he believes can easily be extended to their factivity feature. See the examples in (ii) and especially (iib), which contains a non-presupposed subjunctive relative excluding što. Browne concludes that što relatives can have this complementizer precisely because of their factivity feature:

(ii) a Film što ga je komisija odabrala bio je kupijen. (Browne, 1986: 81, ex. (20a))

film that it Aux-3sg commission chose was Aux-3sg bought

'The film the commission chose was bought'

b. Nema lekara da/*što ne zna za taj slučaj.

there-is-not doctor that not knows of that case

'There isn't a doctor that doesn't know of that case'

The contrast between (i) and (iib), namely the absence of a semantic connection with factivity in Bulgarian as opposed to Serbo-Croatian, gives one more argument against characterizing deto as 'factive' per se. Rather, as argued here, it is a "pure" relative complementizer which has extended its use into the domain of factive clauses.

${ }^{50}$ This complementizer can also introduce a reason clause, and is thus equivalent to English for that, in that, for the reason that, because, cf. e.g. (i). This usage should be clearly kept apart from the 'factive' usage, since it is not selected.

(i) Znam, če me mrazi, zadeto znam, no ne mi puka. zadeto $=$ zaštoto 'because'

know-1sg that me-ClAcc hate-3sg because know-1sg, but not me-CIDat care-3sg

'I know he hates me because I know, but I don't care'
} 
(62) Săžaljavam, zadeto sreštata im se e provalila. regret-1sg for-that meeting-the their refl is failed-prt 'I regret that their meeting has failed'

In fact, this preposition must be spelled out if a PP is coordinated with the 'factive' clause:

(63) Săžaljavam za bileta i *(za)deto propusna predstavlenieto.

regret-1sg for ticket-the and for-that missed-2sg show-the

'I am sorry for the ticket and for [the fact] that you missed the show'

Two pieces of evidence can be provided to show that there is a hidden PP structure underlying factive deto complements. The first comes from extraposition. See (64):

(64) a. *Săžaljavam za tova, văpreki želanieto mi, deto ne možaxme da se sreštnem. regret-1sg for this in-spite-of desire-the my that not could-1pl Mod refl meet-1pl 'I regret that we couldn't meet in spite of my desire'

b. *Săžaljavam văpreki želanieto mi, deto ne možaxme da se sreštnem. regret-1sg for in-spite-of desire-the my that not could-1pl Mod refl meet-1pl

c. ?Săžaljavam, văpreki želanieto mi, za tova, deto ne možaxme da se sreštnem regret-1sg in-spite-of desire-the my for this that not could-1pl Mod refl meet-1pl 'I regret that we couldn't meet in spite of my desire'

d. ?Săžaljavam, văpreki želanieto mi, če ne možaxme da se sreštnem regret-1 sg for in-spite-of desire-the my that not could-1 pl Mod refl meet-1pl 'I regret that we couldn't meet in spite of my desire'

The ungrammaticality of (64a) as a subjacency violation follows if the deto-clause is extraposed from inside a PP which counts for subjacency (cf. Riemsdijk, 1978). The same explanation could carry over to (64b), although here it is also possible that the entire PP has been moved, in which case subjacency could not account for the ungrammaticality of the example. Plausibly, then, the null $P$ head cannot be licensed if it is not adjacent to the verb. Indeed, if the whole PP with an overt $\mathrm{P}$ is moved, the sentence improves considerably, cf. (64c), indicating that in (64b), the null $\mathrm{P}$ is not licensed due to lack of adjacency with the verb. Such an explanation ${ }^{51}$ is strongly reminiscent of Bošković and Lasnik's (2003) account of English null C, according to which null C is lexically specified as an affix, so if for some reason affixation is blocked, the $\mathrm{PF}$ merger of the affix cannot take place. No analogous configuration involving a null $\mathrm{P}$ is to be supposed for the corresponding $\check{c} e$ clause, if the contrast between (64b) and (64d) is taken at its face value, namely the $\check{c} e$ clauses is a sentential complement rather than a relative clause even if embedded under a factive verb.

The second piece of evidence has to do with extraction. The contrast between (65) and (66) shows that while a čecomplement blocks adjunct extraction only, thus qualifying as a weak island, like factive clauses in English, extraction out of a deto-complement reveals a strong island effect, blocking extraction altogether:
a. *Kakvo šăžaljavaš, deto Ivan e napravil takvo? what regret-2sg that Ivan is done-m
b. *Kăde săžaljavaš, deto Ivan e otišâl t tăde? where regret-2sg that Ivan is gone-m
a. Kakvo săžaljavaš, če Ivan e napravil tkakvo? what regret-2sg that Ivan is done-m
b. *Kăde săžaljavaš, če Ivan e otišăl $t_{\text {kăde? }}$ where regret-2sg that Ivan is gone-m

The contrasts in (64) and (65)-(66) would have been unexpected if the behavior of the two complementizers were structurally parallel. If, however, deto complements involve more structure in particular, a DP embedded in a PP all island effects can be accounted for.

\footnotetext{
${ }^{51} \mathrm{I}$ thank an anonymous reviewer for pointing this out to me.
} 


\section{Summary and conclusions}

In this paper, I have discussed complementizer relatives in Bulgarian introduced by the invariant relative complementizer deto and I have argued that they cannot be analyzed by a single derivation, be it Head raising or matching. Rather, both derivations are needed and the choice between them is driven by familiar semantic considerations which require, or block, reconstruction of the overt Head. I showed that the raising derivation is needed to derive relative clauses involving idiomatic readings, amount readings, anaphor and pronominal binding possibilities, and narrow scope interpretations. The matching derivation, on the other hand, is to be applied in all other cases, as the respective structures are exempt from reconstruction effects. I also proposed, following Cinque (2003, 2008), that the two derivations can be accommodated in a single structure if two identical copies of the relative "head" (external Head and internal Head) are postulated for relative clauses cross-linguistically and argued to raise to different positions in the left periphery of the relative clause according to considerations based on Relativized Minimality. The hierarchical structures thus produced allow for the possibility that (depending on the type of the derivation, 'raising' or 'matching') the higher copy of the Head, i.e. the c-commanding copy, deletes the lower copy at PF and is spelled out as the overt relative clause "head".

Island effects have been considered crucial in deciding whether resumptive relatives in Bulgarian, a language that makes productive use of resumption in complementizer relatives, are derived by movement, which, within the current framework "translates" as movement of the internal Head (in addition to the obligatory movement of the external Head). The empirical evidence, based on the absence of island effects showed that no such movement takes place in Bulgarian resumptive complementizer relatives, confirming the observations adduced earlier in the paper that the clitic in such structures behaves as a "true", although not "last resort", resumptive element. The mixed theory of resumption developed in Aoun et al. (2001) allows one to distinguish such resumptives from formally identical ("apparent") resumptives appearing in other contexts and showing the hallmarks of movement. This distinction was derived by adopting a version of the 'clitic doubling' structure proposed in Boeckx (2003) for resumptive relatives, with the proviso however that apart from the movement option, instantiated in languages in which the associate of the resumptive leaves a copy next to it, a second option is also available in languages, like Bulgarian, in which the associate can be shown not to involve movement, but rather in situ deletion.

Lastly, I have discussed several arguments (selectional restrictions, extraposition and island behavior) in favour of analyzing apparent cases of factive deto complements as relative clauses whose head is a covert demonstrative embedded under a PP structure. On a structural level the relative and factive complementizers can be given a unified account, if factive complements are analyzed as hidden relative clauses, as argued here on the basis of their syntactic properties. Other proposals have been made to the same effect in the literature (see in particular Varlakosta, 1994 for Greek $p u$ 'that' clauses, Aboh, 2005 for Gbe relatives and factives, and Arsenijević, 2009 for a general discussion). Pushing such a conclusion to the limit, Kayne (2008) has recently made the proposal that, at least for English, sentential that is a subcase of relative that, so it might as well turn out in the end that factivity is not even at stake, and that all finite sentential complements are in fact relative clauses. I leave the testing of this hypothesis for further research.

\section{Acknowledgements}

A version of this paper was presented at the Third Meeting of the Slavic Linguistic Society, held at the Ohio State University, 10-12 June 2008 and at the Balkan Linguistics conference held at the University of Veliko Tărnovo, Bulgaria, 29 April-02 May 2009. I thank the audiences of these conferences for their questions and discussions. I also thank the two anonymous reviewers for their extremely useful comments regarding some particulars of the analysis and the way it is presented. I am especially grateful to Adam Szczegielniak and Guglielmo Cinque who read, commented, and discussed with me a previous version of this work. Many thanks also go to my colleague Gregory Dowling for help with English.

\section{References}

Aboh, E., 2005. Deriving relative and factive clauses. In: Brugè, L., Giusti, G., Munaro, N., Schweikert, W., Turano, G. (Eds.), Contributions to the Thirtieth "Incontro di Grammatica Generativa". Cafoscarina, Venezia, pp. 265-285. 
Adger, D., Ramchand, G., 2005. Merge and Move: wh-dependencies revisited. Linguistic Inquiry 36, 161-193.

AG, 1983. Gramatika na săvremennija bălgarski knižoven ezik. Tom 3. Sintaksis. BAN, Sofia.

Alexiadou, A., 1998. On the structure of Greek relative clauses. In: Studies in Greek linguistics. Proceedings of the 18th Annual Meeting of the Department of Linguistics, Aristoteles University of Thessaloniki, Thessaloniki, pp. 15-27.

Alexiadou, A., Anagnostopoulou, E., 1999. Asymmetries in the distribution of clitics: the case of Greek restrictive relatives. In: Beukema, F., den

Dikken, M. (Eds.), Clitic Phenomena in European Languages. John Benjamins, Amsterdam, pp. 47-70.

Alexopoulou, T., 2006. Resumption in relative clauses. Natural Language and Linguistic Theory 24, 57-111.

Arsenijević, B., 2009. Clausal complementation as relativization. Lingua 119, 39-50.

Arnaudova, O., 2003. Focus and Bulgarian clause structure. Doctoral Dissertation. University of Ottawa.

Aoun, J., Choueiri, L., 1997. Resumption and last resort. Ms. University of Southern California, Los Angeles.

Aoun, J., Choueiri, L., Hornstein, N., 2001. Resumption, movement, and derivational economy. Linguistic Inquiry 32, $371-403$.

Aoun, J., Li, Y.-H.A., 1990. Minimalist disjointness. Linguistics 28, 189-203.

Aoun, J., Li, Y.-H.A., 2003. Essays on the Representational and Derivational Nature of Grammar. The Diversity of wh-constructions. MIT Press, Cambridge, MA.

Bianchi, V., 1999. Consequences of Antisymmetry: Headed Relative Clauses. Mouton de Gruyter, Berlin.

Bianchi, V., 2004. Resumptive relatives and LF chains. In: Rizzi, L. (Ed.), The Structure of CP and IP. The Cartography of Syntactic Structures, vol. 2. Oxford University Press, Oxford, pp. 76-114.

Bianchi, V., 2008. Some notes on the 'specificity effects' of optional resumptive pronouns. Accessible online at:www.ciscl.unisi.it.

Boeckx, C., 2003. Island and Chains. Resumption as Stranding. John Benjamins, Amsterdam.

Borer, H., 1984. Restrictive relatives in Modern Hebrew. Natural Language and Linguistic Theory 2, 219-260.

Borsley, R.D., 1997. Relative clauses and the theory of phrase structure. Linguistic Inquiry 28, 629-647.

Bošković, Ž., 1997. On certain violations of the Superiority Condition, AgroP, and economy of derivation. Journal of Linguistics 33, 227-254.

Bošković, Ž., 1999. On multiple feature-checking: multiple wh-fronting and multiple head-movement". In: Epstein, S.D., Hornstein, N. (Eds.),

Working Minimalism. MIT Press, Cambridge, MA, pp. 159-187.

Bošković, Ž., 2001. On the Nature of the Syntax-Phonology Interface. Cliticization and Related Phenomena. Elsevier, Amsterdam.

Bošković, Ž., 2002. On Multiple wh-fronting. Linguistic Inquiry 34, 351-383.

Bošković, Ž., in press. On relativization strategies and resumptive pronouns. In: Zybatow, G., Junghans. U., Lenertova, D., Biskup, P. (Eds.), Studies in Formal Slavic Phonology, Morphology, Syntax, Semantics and Information Structure. Proceedings of FDSL 7, Leipzig 2007. Peter Lang, Frankfurt am Mein.

Bošković, Ž., Lasnik, H., 2003. On the distribution of null complementizers. Linguistic Inquiry 33, 527-546.

Brame, M., 1968. A new analysis of the relative clause: evidence for an interpretive theory. Unpublished Manuscript, MIT.

Broihier, K., 1995. Optimality-theoretic Rankings with Tied Constraints: Slavic Relatives, Resumptive Pronouns and Learnability. Ms., Department of Brain and Cognitive Sciences, MIT.

Browne, W., 1986. Relative Clauses in Serbo-Croatian in Comparison with English. Institute of Linguistics, University of Zagreb.

Caink, A., 2000. In favour of a "Clitic Cluster" in the Bulgarian and Macedonian DP. In: Dimitrova-Vulchanova, M., Krapova, I., Hellan, L. (Eds.), Papers from the Third Conference on Formal Approaches to South Slavic and Balkan Languages, Plovdiv 1999. University of Trondheim Working Papers in Linguistics, pp. 170-182.

Carlson, G., 1977. Amount relatives. Language 53, 520-542.

Cecchetto, C., 2000. Doubling structures and reconstruction. Probus 12, 93-126.

Choueiri, L., 2002. Re-visiting relatives: issues in the syntax of resumptive restrictive relatives. Doctoral Dissertation. University of Southern California, Los Angeles.

Chomsky, N., 1965. Aspects of the Theory of Syntax. MIT Press, Cambridge, MA.

Chomsky, N., 1977. On Wh-movement. In: Culicover, P., Wasow, T., Akmajian, A. (Eds.), Formal Syntax. Academic Press, New York, pp. 71-132.

Chomsky, N., 1995. The Minimalist Program. MIT Press, Cambridge, MA.

Chomsky, N., 2000. Minimalist inquiries: The framework. In: Martin, R., Michaels, D., Uriagereka, J. (Eds.), Step by Step. Essays on Minimalist Syntax in Honor of Howard Lasnik. MIT Press, Cambridge, MA, pp. 89-155.

Chomsky, N., 2001. Derivation by Phase. In: Kenstowicz, M. (Ed.), Ken Hale: A life in language. MIT Press, Cambridge, MA, pp. 1-52.

Chomsky, N., 1993. A minimalist program for linguistic theory. In: Hale, K., Keyser, S.L. (Eds.), The View from Building 20: Essays in Linguistics in Honor of Sylvain Bromberger. MIT Press, Cambridge, MA, pp. 1-52.

Cinque, G., 1990. Types of A'-Dependencies. MIT Press, Cambridge, MA.

Cinque, G., 2003. The prenominal origin of relative clauses. Paper presented at the NYU Workshop on Antisymmetry and Remnant Movement, Oct. 31-Nov. 1 2003; at the LSA Summer School at Harvard and MIT in 2005; at the Colloque de Syntaxe et Sémantique à Paris 2007, 4-6 October 2007, and at the XXXIV Incontro di Grammatica Generativa at the University of Padua on February 23 2008. Handout and abstract available at: http://dspace-unive.cilea.it/handle/10278/210 and http://dspace-unive.cilea.it/handle/10278/211.

Cinque, G., 2005. Deriving Greenberg's Universal 20 and its exceptions. Linguistic Inquiry 36, 315-332.

Cinque, G., 2008. More on the indefinite character of the Head of restrictive relatives. In: Benincà, P., Damonte, F., Penello N. (Eds.), Selected Proceedings of the 34th Incontro di Grammatica Generativa, Unipress, Padova. Special issue of the Rivista di Grammatica Generativa, 33, 3-24 (2008). Accessible online at: http://dspace-unive.cilea.it/handle/10278/880.

Cinque, G., 2009. The fundamental left-right asymmetry of natural languages. In: Scalise, S., Magni, E., Bisetto, A. (Eds.), Universals of Language Today. Springer, Dordrecht, pp. 165-184, Available at: http://dpsace-unive.cilea.it/handle/10278/214.

Cinque, G., in preparation. A unified analysis of relative clauses. University of Venice.

Citko, B., 2001. Deletion under Identity in relative clauses. In: Proceedings of NELS 31. GLSA, University of Massachusetts, Amherst, pp. $131-145$. 
Dacheva, G., 2008. Za razvoja na njakoi komplementizatori v novobălgarskija knižoven ezik. Online journal Litera.net available at: www.slav.unisofia.bg/liliJournal/archive/LiLi2/Dacheva20052.htm.

Dacheva, G., Tisheva, Y., 2005. Tradicijata v razgovornite modeli: kojto ili deto. Jubileen slavističen sbornik, Blagoevgrad.

Dimitrova-Vulchanova, M., Giusti, G., 1996. Quantified noun phrases structure in Bulgarian. In: Toman, J. (Ed.), Formal Approaches to Slavic Languages 3. The College Park Meeting. Michigan Slavic Publications, Ann Arbor, pp. 123-144.

Dobrovie-Sorin, C., 1990. Clitic doubling, wh-movement, and quantification in Romanian. Linguistic Inquiry 21, 351-397.

Fiengo, R., May, R., 1994. Indices and Identity. MIT Press, Cambridge, MA.

Franks, S., 2000. The Internal Structure of Slavic NPs, with Special Reference to Bulgarian. In: Generative Linguistics in Poland 2 (syntax and morphology). Proceedings of the GLiP-2 Conference, Institute of Computer Science, Polish Academy of Sciences, Warsaw, pp. 53-70.

Franks, S., Rudin, C., 2005. Bulgarian clitics as $\mathrm{K}^{0}$ Heads. In: Franks, S., Gladney, F., Tasseva-Kurktchieva, M. (Eds.), Formal Approaches to Slavic Linguistics: The South Carolina Meeting. Michigan Slavic Publications, Ann Arbor, pp. 106-118.

Gareiss, K., 1999. Macedonian evidence for synchronic and diachronic parallelism in the development of one Balkanism: the general relativizer što. Indiana Slavic Studies 10, 87-101.

Grosu, A., Landman, F., 1998. Strange relatives of the third kind. Natural Language Semantics 6, 125-170.

Herdan, S., 2008. Degrees and amounts in relative clauses. Doctoral Dissertation. University of Connecticut.

Ivančev, S., 1978. Prinosi v bălgarskoto i slavjanksoto ezikoznanie. Nauka i izkustvo, Sofia.

Izvorski, R., 1993. On the semantics of the Bulgarian "indefinite article". In: Avrutin, S., Franks, S., Progovac, L. (Eds.), Annual Workshop on Formal Approaches to Slavic Linguistics. The MIT Meeting. Michigan Slavic Publications, Ann Arbor, pp. 235-254.

Izvorski, R., 1995. Wh-movement and focus-movement in Bulgarian. In: Eckardt, R., Geehoven, Van, V. (Eds.), ConSole II: Proceedings of the Second Conference of the Student Organization of Linguistics in Europe, Holland Academic Graphics, The Hague, pp. 54-67.

Kallulli, D., 2008. Clitic doubling, agreement and information structure. In: Kallulli, D., Tasmowski, L. (Eds.), Clitic Doubling in the Balkan Languages. John Benjamins, Amsterdam, pp. 227-256.

Karabelova, G., 1998. Ob odnoj osobenosti složnopodčinennyx predloženij s opredeliteljnoj pridatočnoj častju. In: Slavistika. Plovdivski universitet "Paisij Hilendarski", Plovdiv.

Kayne, R.S., 1972. Subject inversion in French interrogatives. In: Casagrande, J., Saciuk, B. (Eds.), Studies in Romance Languages. Newbury House, Rowley, MA, pp. 70-126.

Kayne, R.S., 1994. The Antisymmetry of Syntax. MIT Press, Cambridge, MA.

Kayne, R.S., 2002. Pronouns and their antecedents. In: Epstein, S.D., Seely, T.D. (Eds.), Derivation and Explanation in the Minimalist Program. Blackwell, Oxford, pp. 133-166.

Kayne, R.S., 2004. Prepositions as probes. In: Belletti, A. (Ed.), Structure and Beyond: The Cartography of Syntactic Structures, vol. 3. Oxford University Press, Oxford, pp. 192-212.

Kayne, R.S., 2008. Why isn't this a complementizer. In: Svenonius, P., et al. (Eds.), Functional Structure from Top to Toe. Available at: http:// ling.auf.net/lingBuzz/000726.

Kiparsky, P., Kiparsky, C., 1971. Fact. In: Steinberg, D.D., Jakobovits, L.A. (Eds.), Semantics: An Interdisciplinary Reader in Philosophy, Linguistics and Psychology. Cambridge University Press, Cambridge, pp. 345-369.

Koopman, H., Sportiche, D., 2008. The que/qui alternation: new analytical directions, In: Svenonius, P., et al. (Eds.), Functional Structure from Top to Toe. Available at: http://ling.auf.net/lingBuzz/000638.

Krapova, I., 2002. On the left periphery of the Bulgarian sentence. University of Venice Working Papers in Linguistics, vol. 12. pp. 107-128.

Krapova, I., Cinque, G., 2008a. On the order of multiple wh-questions in Bulgarian multiple wh-fronting. In: Zybatow, G., Szucsich, L., Junghans, U., Meyer, R. (Eds.), Formal Description of Slavic Languages: The Fifth Conference, Leipzig 2003. Peter Lang, Frankfurt am Main, pp. 318336.

Krapova, I., Cinque, G., 2008b. Clitic reduplication constructions in Bulgarian. In: Kallulli, D., Tasmowski, L. (Eds.), Clitic Doubling in the Balkan Languages. John Benjamins, Amsterdam, pp. 257-288.

Kroch, A., 1981. On the role of resumptive pronouns in amnestying island constraint violations. In: Proceedings of CLS 17, Chicago Linguistic Society, Chicago, Illinois, pp. 125-135.

Lakoff, G., 1972. Linguistics and natural logic. In: Davidson, D., Harman, G. (Eds.), Semantics of Natural Language. Reidel, Dordrecht, pp. 545665.

Lasnik, H., Stowell, T., 1991. Weakest Crossover. Linguistic Inquiry 22, 687-720.

Lavine, J.E., 2003. Resumption in Slavic. In: Browne, W., Kim, J.-Y., Partee, B.H., Rothstein, R.A. (Eds.), Formal Approaches to Slavic Linguistics 11. The Amherst Meeting 2002. Michigan Slavic Publications, Ann Arbor, pp. 355-372.

Maslov, Ju., 1982. Gramatika na bălgarskija ezik. Sofia, Nauka i izkustvo.

McCloskey, J., 1990. Resumptive pronouns, A'-binding, and levels of representation in Irish. In: Hendrick, R. (Ed.), The Syntax of Modern Celtic Languages. Academic Press, New York, pp. 199-248.

McCloskey, J., 2002. Resumption, successive cycliticty, and the locality of operations. In: Epstein, S.A., Seely, T.D. (Eds.), Derivation and Explanation in the Minimalist Program. Blackwell, Oxford, pp. 184-226.

McCloskey, J., 2006. Resumption. In: Everaert, M., Riemsdijk, H., van, (Eds.), The Blackwell Companion to Syntax. Blackwell, Oxford, pp. 94-117.

McNally, L., 2008. DP-internal only, amount relatives, and relatives out of existentials. Linguistic Inquiry 39, 161-169.

Milsark, G., 1974. Towards an explanation of certain peculiarities of the existential construction in English. Linguistic Analysis 3, 1-30.

Nitsolova, R., 1986. Bălgarskite mestoimenija. Nauka i izkustvo, Sofia.

Penčev, I., 1998. Sintaksis na săvremennija bălgarski knižoven ezik. Plovdiv.

Pesetsky, D., 1998. Some optimality principles of sentence pronunciation. In: Barbosa, P., Fox, D., McGinnis, M., Pesetsky, D. (Eds.), Is the best good enough? Optimality and Competition in Syntax. MIT Press, Cambridge, MA, pp. 337-383. 
Pesetsky, D., 2000. Phrasal Movement and its Kin. MIT Press, Cambridge, MA.

Richards. N., 1997. What Moves Where When in Which Language? Doctoral Dissertation. Massachusetts Institute of Technology, Cambridge. Richards, N., 2001. Movement in Language: Interactions and Architectures. Oxford University Press, Oxford.

Riemsdijk, H. van, 1978. A Case Study in Syntactic Markedness: The Binding Nature of Prepositional Phrases. Foris, Dordrecht.

Riemsdijk, H. van, 1989. Swiss relatives. In: Jaspers, D., Klooster, W., Putseys, Y., Seuren, P. (Eds.), Sentential Complementation and the Lexicon. Foris, Dordrecht, pp. 343-354.

Rizzi, L., 1997. The fine structure of the left periphery. In: Haegeman, L. (Ed.), Elements of Grammar. Kluwer, Dordrecht, pp. $281-337$.

Rizzi, L., 2001. Relativized Minimality Effects. In: Baltin, M., Collins, C. (Eds.), The Handbook of Contemporary Syntactic Theory. Blackwell, Oxford, pp. 89-110.

Ross, J.R., 1967. Constraints on variables in syntax. Doctoral Dissertation. MIT.

Rouveret, A., 2002. How are resumptive pronouns linked to the Periphery? Linguistic Variation Yearbook. vol. 2. John Benjamins, Amsterdam, pp. 123-184.

Rouveret, A., 2007. Phrasal agreement and reconstruction. In: Freidin, R., Otero, C.P., Zubizarreta, M.L. (Eds.), Foundational Issues in Linguistic Theory. Essays in Honor of Jean-Roger Vergnaud. MIT Press, Cambridge, MA, pp. 167-196.

Rudin, C., 1986. Aspects of Bulgarian Syntax: Complementizers and Wh Constructions. Slavica Publishers, Columbus, Ohio.

Rudin, C., 1988. On multiple questions and multiple wh-fronting. Natural Language and Linguistic Theory 6, 455-501.

Safir, K., 1999. A-bar reconstruction and vehicle change in A-bar chains. Linguistic Inquiry 30, 587-621.

Salzmann, M., 2006. Resumptive Prolepsis. A study in indirect A'-dependencies. LOT, Utrecht, The Netherlands.

Sauerland, U., 1998. The meaning of chains. Doctoral Dissertation. MIT.

Sauerland, U., 1999. Two structures for English restrictive relative clauses. In: Proceedings of the Nanzan GLOW, Nanzan University, Nagoya, Japan, pp. 351-366.

Sauerland, U., 2003. Unpronounced heads in relative clauses. In: Schwabe, K., Winkler, S. (Eds.), The Interfaces. Deriving and Interpreting Omitted Structures. John Benjamins, Amsterdam, pp. 205-226.

Schachter, P., 1973. Focus and relativization. Language 49, 19-46.

Sells, P., 1984. Syntax and semantics of resumptive pronouns. Doctoral Dissertation. University of Massachusetts, Amherst.

Shlonsky, U., 1992. Resumptive pronouns as a last resort. Linguistic Inquiry 23, 443-468.

Stavrou, M., 1984. The clitic pronoun in restrictive relative clauses that are introduced by 'pu'. Studies in Greek Linguistics 2, 121-136.

Suñer, M., 1998. Resumptive restrictive relatives. a cross-linguistic perspective. Language 74, 335-364.

Szczegielniak, A., 2005. Relativization that you did... MIT Occasional Papers in Linguistics, vol. 24, Cambridge, MA.

Toman, J., 1998. A discussion of resumptives in Colloquial Czech. In: Bošković, Ž., Franks, S., Snyder, W. (Eds.), Formal Approaches to Slavic Linguistics 6: The Connecticut Meeting 1997. Michigan Slavic Publications, Ann Arbor, pp. 303-318.

Tomić, O., 2006. Balkan Sprachbund Morpho-syntactic Features. Springer, Dordrecht.

Topolinjska, Z., 1997. Relativization—a strategy for noun phrase complementation? (Relative Clauses in the Macedonian Tărlis manuscript). Balcanistica 10, 292-381.

Torrego, E., 1998. The Dependencies of Objects. MIT Press, Cambridge, MA.

Uriagereka, J., 1995. Aspects of the syntax of clitic placement in Western Romance. Linguistic Inquiry 26, 79-123.

Van der Auwera, J., Kučanda, D., 1985. Pronoun or conjunction—the Serbo-Croatian invariant relativises što. Linguistics 23, 917-962.

Varlakosta, S., 1994. Factivity, factive complements and wh-extraction. MIT Working Papers in Linguistics 23, 317-336.

Vergnaud, R., 1974. French relative clauses. Doctoral Dissertation. MIT. 